\title{
Chapter 40 \\ When Micro Drives the Macro: A Fresh \\ Look at Disease and its Massive \\ Contributions in the Hindu \\ Kush-Himalaya
}

\author{
Tirth Raj Ghimire, Ganga Ram Regmi, and Falk Huettmann
}

\subsection{Introduction}

Due to changing climates, the 'new' modes of living by the people, and increased natural disasters, unprecedented outbreaks of emerging and reemerging diseases have been occurring since many years by now. Their outbreaks have been further critically important in the public and for veterinary health because of their immediate effects leading to disability, death and long-term illness of humans and animals. It's clearly a society issue and dealing with the wider public health, now on a global scale. Thus, with the emergence of suitable climates, vectors, and hosts, microspecies (ms) like viruses, rickettsia, bacteria, protozoa, helminths, and fungi actually are the underlying causes of high morbidity and mortality of macrospecies (MS) like humans, animals, and plants in a wide geographic condition. That is why presence of ms can determine the survival value of the MS with reference to geography and time. The aim of this chapter is to explain a clear causal understanding of the diseases, their causal agents (e.g., ms), and the hosts (e.g., MS) in the context of Nepal, a well-known country in the Hindu Kush-Himalaya $(\mathrm{HKH})$ region and a

Publisher's Note - Springer Nature remains neutral with regard to jurisdictional claims in published maps and institutional affiliations.

\footnotetext{
T. R. Ghimire $(\bowtie)$

Animal Research Laboratory, Faculty of Science, Nepal Academy of Science and Technology (NAST), Khumaltar, Lalitpur, Nepal

e-mail: tirth.ghimire@ nast.gov.np

G. R. Regmi

Third Pole Conservancy, Kathmandu, Nepal

F. Huettmann

-EWHALE Lab- Institute of Arctic Biology, Biology \& Wildlife Department, University of Alaska Fairbanks, Fairbanks, AK, USA
} 
typical example of complex landscapes in terms of altitudinal gradients, climate, bio-diversity, watersheds and culture.

\subsection{Biodiversity of Nepal}

Nepal makes for an inherent part of the wider HKH region that comprises all of Bhutan and the mountainous parts of Afghanistan, Bangladesh, China, India, Myanmar, and Pakistan; it also reaches further than those nations. Physiographic and bioclimatic zones range from less than $500 \mathrm{~m}$ of terai to more than $5000 \mathrm{~m}$ of high Himalayan region (GoN/MoFSC 2014). Thus, the northern or Himalayan region of the country accounts for the $15 \%$ of the area. The central belts or middle hills occupy $68 \%$ of Nepal. The southern low-lying plain or terai region is susceptible to flooding following monsoon and occupies 17\% of the country (Amatya 2016). In addition to this altitudinal landscape, there are a total of 118 different ecosystems with 112 forest ecosystems, 4 cultivation ecosystems, 1 water body ecosystem, and 1 glacier/snow/rock ecosystem (GoN/MoFSC 2014). This variety of ecosystem accompanied with the landscape differences are the underlying cause of existence of various floral and faunal diversities. For example, the flora comprises the tropical and subtropical rainforest, temperate broadleaved-deciduous or mixed forest, and temperate coniferous forest with high-altitude cold shrub or steppe and cold desert (Lamadrid and Kelman 2012). The country is a habitat for a total of 208 species of mammals (Jnawali et al. 2011), 879 species of birds (Shrestha 2000), 206 species of herpetofauna including 59 amphibian species (Shrestha 2001), 232 species of fish fauna (Shrestha 2008b), 138 species of molluscs (Budha et al. 2015), and 17 species of domestic animals including 5 bovidae, 7 Aves, 2 Equidae (not including mules), pig (Sus scrofa), rabbit (Oryctolagus cuniculus), and elephant (Elephas maximus) (Wilson 1997). This sets the stage for zoonotic diseases and for a disease reservoir.

Due to ecologic diversities, Nepal is highly preferable to the local people and outsiders. It possesses complex socio-economic, religious, ethnic, linguistic, cultural, and socio-health diversities. These diversities along with other factors like climate change, population dynamics, and land use changes and globalization directly or indirectly determine the health status of animals and humans alike. Among these factors, climate change primarily leads to a deterioration of water quality, degrades air quality with a high concentration of pollutants like nitrogen dioxide and airborne-particles, increases lower tropospheric and ground-level ozone levels, and finally follows systematic temperature increase, for example, 0.01-0.04 ${ }^{\circ} \mathrm{C}$ per annum enhances the spread of disease agents at higher elevations at which they did not occur before (Sarkar 2011). 


\subsection{The Traditional Understanding of Disease}

Disease means any abnormality that affects the structure and function of a part of body, organ, tissue, cell, or a molecule of an organism. Disease may be caused by various smaller species, so called ms such as viruses, bacteria, rickettsia, fungi, protozoa, helminths, and arthropods. Interestingly, these ms have been denoted as 'agents' in the epidemiologic triad in which antibiotic resistivity, antigenic stability, antigen expressions, dose, enzyme production, host specificity, host survival, immunogenicity, infectivity, virulence, toxicity, pathogenicity, reservoirs, sources, and modes of dissemination of ms play a critical role (Wilber et al. 2017; Keane 1997; Ghimire 2014) (Fig. 40.1). In this triad, hosts including humans and animals, or MS in this text, are those species that harbor the disease agents or ms. The age, behavior, genotype, and hormonal, immune, nutritional, occupational, physiological, and socio-economic status of the MS play the role in epidemiologic triad. The MS may act as reservoir, definitive, transport, intermediate hosts, and carriers for the successful adaptation to the agents.

The ms is either directly transmitted via direct contact (e.g., HIV, Treponema pallidum), droplet infection (Mycobacterium tuberculosis), contact with soil (e.g., Ascaris, Ancylostoma, Enterobius), trans-placental (e.g., Leishmania, Toxoplasma), food (e.g., Coccidia, Fasciola, Clonorchis), water (e.g., Coccidia), sexual contact or inoculation into skin or mucosa (e.g., HIV, Treponema pallidum, Trichomonas fetus, T. vaginalis). In addition, indirect transmission through vehicle (e.g., mosquitoes, bedbugs, lice), air (e.g., Ascaris, Enterobius), fomite (e.g., Salmonella), finger (e.g., foodborne pathogens), and various arthropods (eg Plasmodium, Trypanosoma, Leishmania) or molluscan vectors (e.g., Fasciola, Clonorchis) occurs in various diseases. These vectors can obtain the ms during feeding the nutrients like amino acids and non-nutrients like blood of the MS. The ms can enter into the body of the suitable MS via different portals of entry, for example, the mouth (e.g., gastrointestinal or GI pathogens), eyes (e.g., Loa loa, Thelazia callipaedia, Acanthamoeba), ear (e.g., Otobius), nose (virus, Oestrus ovis, Acanthamoeba, and Naegleria), anus (e.g., Giardia lamblia, Cryptosporidium, Strongyloides, Enterobius), genital organs like vagina and penis (Trichomonas vaginalis, HIV, Treponema pallidum), and skin (Ancylostoma, Strongyloides, Plasmodium, Leishmania).

When the ms enter into the body, they search for a suitable environment and multiply and initiate the disease depending on the immune system of MS. It is, therefore, important to determine early enough whether symptoms may appear or not at this stage. Finally, ms exit out of the body via urino-genital (e.g., HIV), respiratory (Mycobacterium), and digestive system (e.g., GI parasites). As a result, the $\mathrm{ms}$ is transmitted into environment containing reservoirs or into another MS directly, or into arthropod, annelid, molluskan, and mammalian vectors. In these contexts, reservoir is a natural habitat of ms that includes MS (e.g., all pathogens), arthropod like insects (e.g., Plasmodium, Leishmania), arachnids (Sarcoptes scabei), and mollusks (e.g., Schistosoma, Fasciola, Clonorchis), plant (e.g., Fasciola), soil (Coccidia, Ascaris, Clostridium tetani), or substance, or a combination of them in which an ms 


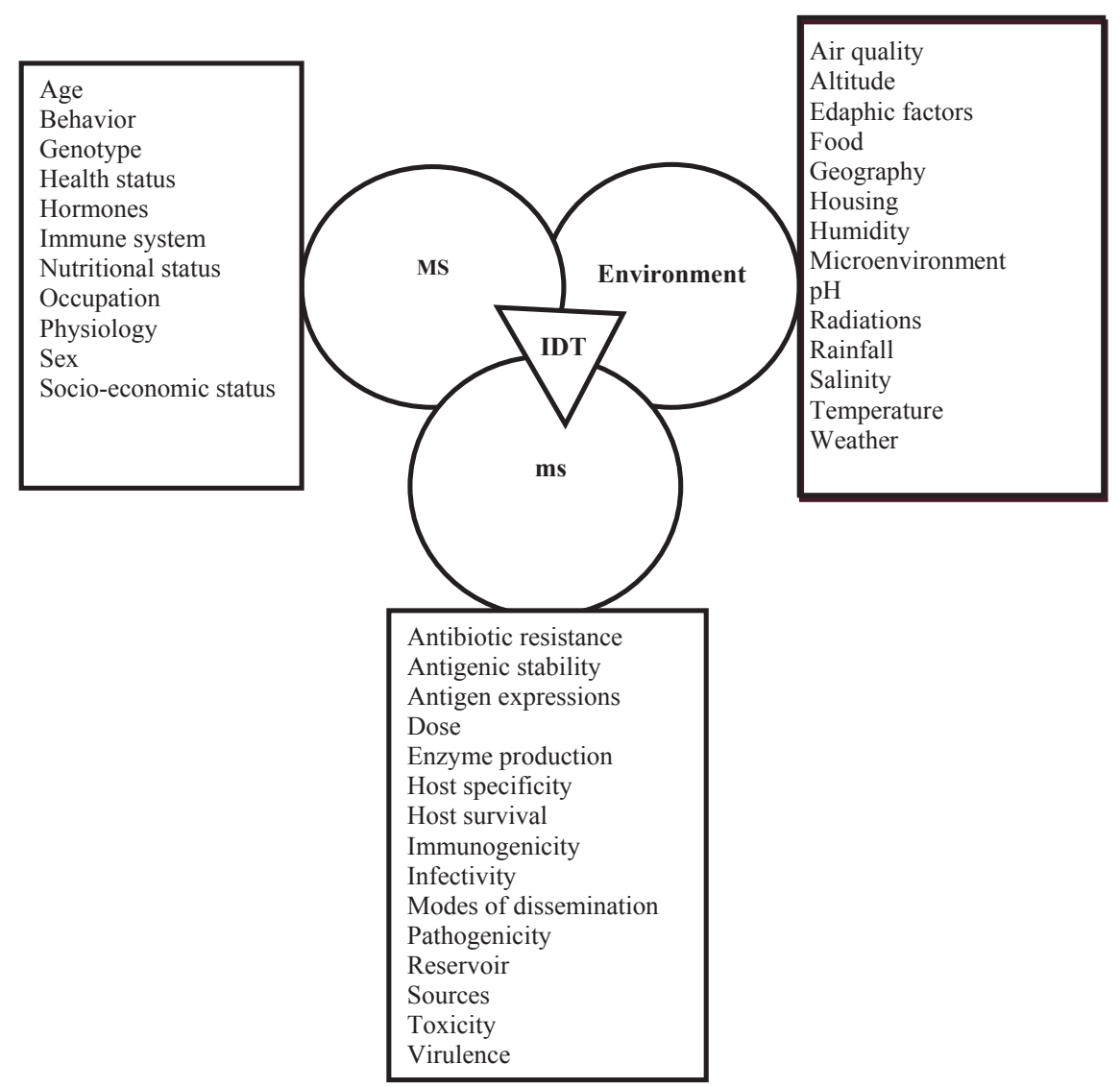

Fig. 40.1 Understanding of diseases based on the traditional 'Infectious Disease Triad Model'. To transmit, initiate, and establish disease, various factors of MS, ms, and environment play a critical role with reference to geography and time. The triad can be used to assess the role of pathogens in morbidity and mortality following outbreaks of diseases. Modified after (Keane 1997; Ghimire 2014; Snieszko 1974). MS macrospecies, ms microspecies, IDT Infectious Disease Triad

normally lives, grows, and adapts leading rapid multiplication in a fashion that it can be transmitted to a suitable host. This pattern of chain of infection involving a series of journey of ms from reservoirs to susceptible hosts through various modes of transmission produces the dynamics of disease transmission. In this context, the third member of epidemiologic triad or the environmental factors such as climate, temperature, humidity, micro-and macro-environment, topography, zoogeography, host specificity, light, salinity, $\mathrm{pH}$ (hydrogen ion concentration), percent gases, soil, water, food quality, and nutrients are important. These factors determine the successful invasion, establishment, and transmission of the ms leading outbreaks of the diseases and morbidity and mortality of the MS (Ghimire 2014; Yan et al. 2016; Si et al. 2010; Roberts and Wiedmann 2003; Keane 1997). 


\subsection{Contribution of Microspecies (ms) to Diseases in Macrospecies (MS) in Nepal}

The public and veterinary health reports indicate that Nepal is vulnerable to increased rate of morbidity and mortality of MS by various underlying causes such as ms, natural calamities, climate change, plant and pesticide poisoning, noncommunicable diseases, antibiotic resistivity, road accidents, and intra- and interspecific competition (DoAH 2015, 2016a, b; DoHS 2012, 2016, 2017) (Fig. 40.2). Among these underlying factors, the role of $\mathrm{ms}$ is critical because they may induce immediate and rapid mass mortality of MS leading susceptibility to endangerment and extinction (Field et al. 2009; Fey et al. 2015; González-Suárez and Revilla 2014; Smith et al. 2006; Pedersen et al. 2007; Adams et al. 2017). For example, mass elimination of Mongolian saigas by Peste des Petits Virus (PPRV) (Chimeddorj and Buuveibaatar 2017), of amphibian populations by Ranavirus, Batrachochytrium dendrobatidis, and Perkinsea (Fey et al. 2015; Cheng et al. 2011; Duffus et al. 2015; Isidoro-Ayza et al. 2017; Kwon et al. 2017; Geng et al. 2011), and of humans and

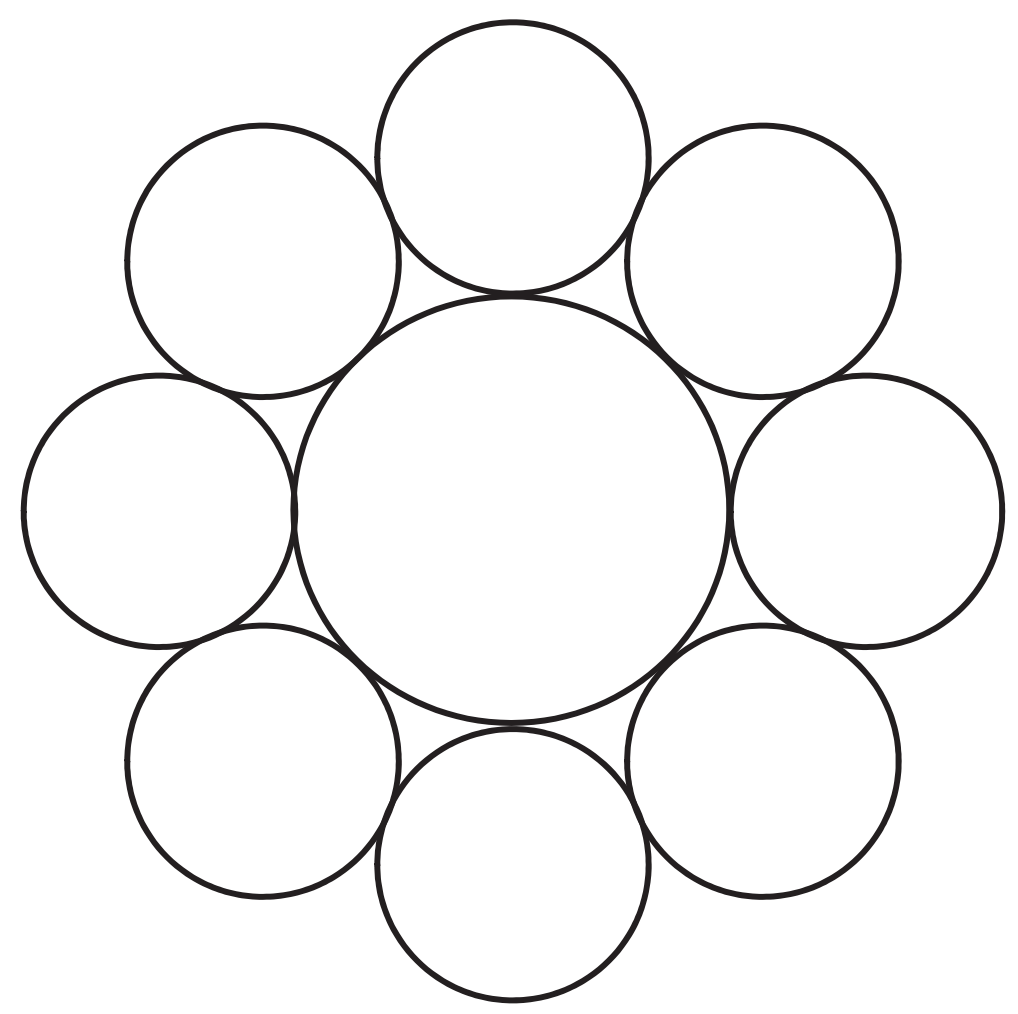

Fig. 40.2 Underlying causes of MS decline. Antibiotic resistivity, plant and pesticide poisoning, climate change, natural calamities, ms, road accidents, and intraspecific and interspecific competition variously decline the MS populations 
animals by TB, influenza, acute respiratory, and diarrheal pathogens has been already reported around the world (NRC 1993; Gates 2014; DoAH 2016b; DoHS 2017). In these contexts, although several causes might exist, extreme virulence, toxicity, and the pathogenicity of the pathogens actually govern the disease appearance and outbreaks. Thus, understanding the role of ms in causing many food- and water-borne, vector-borne, and zoonotic diseases would make sense in veterinary and public health. In this review, the contribution of ms to disease susceptibility, morbidity, and case fatality rate (CFR) data of cattle, yak, buffalo, goat, sheep, pig, birds, dog, and horses have been expressed based on the reports published by of the Government of Nepal (GoN) (DoAH 2016b).

\subsection{Viral Infections Leading to MS Decline}

Although the reports of viral infections in wild fauna are scarce, several natural, sporadic, epidemic, endemic, epizootic, zooanthroponotic, and anthrozooponotic viral infections those in the livestock of the country are available. One serologic study confirmed the cercopithecine herpsevirus $1(\mathrm{CHV}-1)$, rhesus cytomegalovirus (RhCMV), Cercopithecine herpesvirus 1 (CHV-1), and simian foamy virus (SFV) in Rhesus macaque Macaca mulatta in Kathmandu valley indicating their critical role in zoonosis (Jones-Engel et al. 2006). Various fatal viral diseases including avian influenza, canine distemper, human corona, coronavirus disease 2019 (COVID-2019), rabies, and several others have been reported from the country.

\subsubsection{Avian Infectious Bronchitis (AIB)}

AIB is an acute and highly contagious disease of a wide range of birds including chicken caused by an enveloped, pleiomorphic, positive-sense, and non-segmented single-stranded (ss) RNA AIB virus called a coronavirus that falls in the genus Gammacoronavirus within family Coronaviridae (Cavanagh 2007; Zanaty et al. 2016; Liu et al. 2005; Boursnell et al. 1987). AIB not only causes a severe respiratory distress but also leads to renal and reproductive tract dysfunction resulting in the reduction of quality and quantity of the egg and meat production (Cavanagh 2007). The disease is predominant in many areas with large commercial poultry population including both layers and broilers of all ages with high mortality. Nepal is one of them in which several outbreaks have occurred resulting in a high morbidity and about 17.5\% CFR (Cavanagh 2007; DoAH 2016b). 


\subsubsection{Avian Influenza}

Avian (Bird) flu, caused by the avian flu virus, has an enveloped, segmented, and negative-sense ssRNA that falls in genus Influenza $A$ and family Orthomyxoviridae. The virus contains surface proteins hemagglutinin $(\mathrm{H})$ and neuraminidase $(\mathrm{N})$ and produces $16 \mathrm{H}$ subtypes (H1-H16) and $9 \mathrm{~N}$ subtypes (N1-N9) in avian hosts. This virus is classified into the low pathogenic (LPAIV) or highly pathogenic (HPAIV) strains based on their lethality (Alexander 2000b). Although both strains are transmissible via feces, saliva, nasal secretions, the HPAIV strain causes $100 \%$ mortality, even within $48 \mathrm{~h}$ (CDC 2017). On the other hand, the pathogenicity of LPAIV can be enhanced by other infections or environment conditions (Alexander 2000b). The Influenza $A$ virus has been isolated from more than 100 different species of wild aquatic birds that can act as reservoirs maintaining the viruses in nature (CDC 2017), however, reports of detection of other genera like Influenza $B$ are from humans and seals (Osterhaus et al. 2000; Kato et al. 2015) and those of Influenza $C$ are from humans, pigs, and dogs (Matsuzaki et al. 2002; Youzbashi et al. 1996).

It should be important to note that migratory birds spread the Influenza A viruses to the geographically unrelated regions. In the eastern part of the country, outbreaks of an H5N1 avian flu occurred in January 2009. Since then, several outbreaks led mass mortality of commercial and household chickens and ducks (WHO 2012). In addition, the GoN killed several thousands of chicken and eggs to prevent the viral spread (CIDRAP 2017; Gautam 2012). The strain, H5N1 serotype, has been evidenced to kill chicken and ducks in the high altitude area (OIE 2017b), whereas both $\mathrm{H} 5 \mathrm{~N} 1$ and H5N8 have killed several chicken, Asian Openbill (Anas tomus oscitans), and the Whooper Swan (Cygnus cygnus) in the low altitude area (OIE 2017a) suggesting Nepal to be highly endemic region for HPAI despite Her geography. One study found H9N2 in the stool of a ruddy shelduck (Tadorna ferruginea) in seven wetland migratory bird roosting areas (Karmacharya et al. 2015). This suggested that this strain leads to endemicity in poultry and may evolve into H7N9 to facilitate transmission into human (Liu et al. 2014; Chen et al. 2014). Only one case of death of a 21-year-old male following the H5N1 infection was reported on March 29, 2019 in Nepal (Shrestha 2019) suggesting that the virus rarely spreads from birds to humans and there is no proof of the viral spread from human to human till date. However, pandemic Influenza $A$ by the H1N1 strain has become a critical problem of public health (Adhikari et al. 2011; Anonymous 2018). Avian influenza is also critical in this country because of the full of various migratory birds in and around the Kathmandu Valley, major rivers like Karnali, Gandaki, and Koshi river, and wildlife reserves at the lowland regions in Nepal, and from China, Mongolia, Korea, Siberian region of Russia, and central Asia in the winter seasons. This is because one of the birds, wild waterfowl, have been shown to act as the natural reservoirs of LPAI and transmitters of LPAIV along migratory routes in Asia, Africa, and the Americas (Webster et al. 1992; Munster et al. 2007; Cappelle et al. 2012; Spackman et al. 2005). 


\subsubsection{Canine Distemper Disease (CDD)}

CDD or hardpad disease, a highly contagious via inhalation, is caused by a negativesense ssRNA virus of the genus Morbillivirus within the family Paramyxoviridae (Sykes 2014). It affects a wide members of families like canidae, mustelidae, cercopithecidae, procyonidae, ailuridae, ursidae, elephantidae, vivirridae, and felidae (Creevy 2018). The virus has been detected in $27 \%$ of domestic dogs in the buffer zone of a national park indicating a high risk factor for the wild fauna in Nepal (Dudley 2017) and Canine Distemper Viral antibodies in more than $70 \%$ of the examined dogs with $13 \%$ prevalence of P-gene in $13 \%$ in the 10 villages in Nepal's Annapurna Conservation Area at high altitude suggesting predominance of this virus in the national park areas and in this scenario, risk may exist during transmission of virus from feral dogs to wild carnivores in the nearby zones ( $\mathrm{Ng}$ et al. 2019). The virus has been hypothesized to lead endangerment process of Canis lupus, Cuon alpinus, and Canis aureus in the country (Dudley 2017).

\subsubsection{Classical Swine Fever (CSF)}

CSF or Hog Cholera is an acute and chronic disease caused by the enveloped ssRNA virus that falls in the genus Pestivirus within the family Flaviviridae (Blome et al. 2017). The disease naturally occurs in domestic and wild pigs. Although genotypes similar to Indian regions have been identified in Nepal indicating the imported cases, other genotypes have been recorded proving Nepal to be endemic country for CSF (Postel et al. 2013). Few outbreaks in the Nepalese pig populations have led very high CFR, quantitatively about $60 \%$. The GoN has not been able to issue certification process to ensure the quality and disease free status of pigs and as a result, exports of pigs and pork to China, India, Bhutan, Thailand, Vietnam, and Hong Kong have been very difficult indicating an existence of huge impact on Nepalese economy by the disease (PEAN 2016).

\subsubsection{Contagious Pustular Dermatitis (CPD)}

$\mathrm{CPD}$, a rare zoonotic disease, is caused by the double-stranded (ds) DNA virus called CPD virus (CPDV) or Orf virus (ORFV) of the genus Parapoxvirus (Matthews 1979). In Nepal, CPD primarily infects sheep and is critically important in their orphan lambs (Scott 2009; Gameel et al. 1995; Abu Elzein and Housawi 1997). 


\subsubsection{Foot-and-Mouth Disease (FMD)}

FMD is caused by a FMD virus that falls in the genus Aphthovirus of the family Picornaviridae and is characterized with the basic picornaviral structure that exists the various serotypes (Fry et al. 1999). Most importantly, the serotypes O (lineages O/ME-SA/PanAsia-2 and O/MESA/Ind-2001d), Asia 1, A, and C have been isolated from Nepal (FAO/EuFMD 2020; OIE 2017c; Chhetri et al. 2010; Ferris et al. 1992; VEC 2016). FMD represents an endemic infection since the time immemorial because it is found in almost all parts of the Himalayan nation during the year (DoAH 2016a). Its outbreak has been reported in blackbucks (Antelope cervicapra) in the Blackbuck Conservation Area in the Western part of the country indicating the possibility of FMD transmission to other endangered fauna (Anonymous 2009). It is principally found in elephants and cloven-footed domestic animals including cattle, buffalo, goats, sheep, and pigs and wild species, however, indigenous and improved breeds of these animals are highly susceptible (DoAH 2016a; Shrestha and Upadhyaya 2016). Its epidemiology in cattle, buffaloes, goats, and pigs is similar, whereas in sheep and yak, it is different. This pattern of MS-wise ms epidemiology is eco-zonal because cattle, buffaloes and goats are domesticated in terai and hilly areas and in contrast, sheep and yak are reared mostly in the mountain region. Interestingly, it has been reported that about $54 \%$ of elephants following migration on foot from the low altitude to the Kathmandu valley got infection probably from water buffaloes on the way (Kitching et al. 1988).

Although size of human and buffalo populations and the numbers of technicians were associated with the increased risks of FMD (Chhetri et al. 2010), its outbreaks are epidemiologically linked to a. the mass migration of animals livestock in the grazing sites, local markets, established trading routes b. movement of infected small ruminants around households, and c. seasonal migration of livestock and other animals from Tibetan plateau to Nepal and vice versa (Ferris et al. 1992). In the September and October in festive, goats are taken from Tibet to the larger cities of Nepal and in the December and January, bullocks and cattle are collected and purchased in the border areas of India enhancing the modes of transmission around the region. China did not allow Nepalese dairy product (butter) to enter into its country during 2001/2003 due to presence of FMD creating a major hurdle in international trade (VEC 2016). Due to the lack of certification and traceability of FMD and resulting its doubts in the pig farms, Chinese have stopped purchasing pigs via Rasuwagathi border at northern part of Nepal (PEAN 2016).

The reports of several FMD outbreaks per annum with high morbidity and mortality have been published in this country (VEC 2016; FAO/EuFMD 2020). The outbreaks seem to be seasonal. The first rise in the number of FMD outbreaks during pre-monsoon and monsoon periods might have been due to excessive movement of animals for summer agricultural operations that favor the spread of disease resulting in to more outbreaks (Thakuri 2012). Although numerous works have been undertaken for the research of FMD in livestock, concerned authorities have not opened their eyes toward opening the primary data on wild fauna in Nepal. The 
crucial role of FMD in declining the fauna includes lack of proper implementation of animal movement regulations, immunization, and the lack of research.

\subsubsection{Fowlpox}

Fowlpox is a disease of chicken, turkeys, quail, canaries, and pigeons caused by dsDNA virus of the genus Avipoxvirus of the family Poxviridae (Afonso et al. 2000). It is transmitted via the biting of mosquitoes and via inhalation. Fowlpox is the underlying cause of the several outbreaks with a high morbidity and about $8.3 \%$ CFR in the chicken in Nepal (DoAH 2016b).

\subsubsection{Infectious Bursal Disease (IBD) or Gumboro Disease}

Infectious bursal disease (IBD), popularly known as Gumboro disease in the Himalayan countries, is a highly contagious and immunosuppressive disease of young chicken caused by IBD virus (IBDV) that is a naked icosahedral virus with segmented dsRNA belonging to the genus Avibirnavirus of the family Birnaviridae (Dobos et al. 1979; Khatri and Sharma 2007). IBD is responsible for not only the direct losses via death of chickens but also the IBDV-induced immunodeficiency that is the underlying cause of secondary infection by viral, bacterial, and parasitic infections leading peaked morbidity, mortality, and disability and finally the huge loss in the poultry industry around the globe (Berg 2000; Zachar et al. 2016). The disease is responsible for a large numbers of outbreaks with high morbidity and about 5.8\% CFR in chicken in Nepal (DoAH 2015, 2016a, b).

\subsubsection{Marek's Disease (MD)}

Marek's disease is a highly contagious neoplastic disease caused by dsDNA virus and its species is called Marek's disease virus (MDV) or gallid alphaherpesvirus 2 (GaHV-2) of the genus Mardivirus within the Herpesviridae family (Nair and Dunn 2018) (Boodhoo et al. 2016). Although the disease may infect chicken with different syndromes like acute, neurolymphomatosis, cutaneous, ocular, atherosclerosis, and immunosuppression with few outbreaks and high morbidity, it has not been reported in other birds in the Nepal (Nair and Dunn 2018). 


\subsubsection{New Castle Disease (NCD)}

New Castle Disease (NCD) is caused by a helical capsid containing non-segmented, negative-sense ssRNA virus. It is an avian paramyxovirus serotype-1 that falls in the genus Avulavirus within the family Paramyxoviridae (Dortmans et al. 2011; Alexander and Senne 2008; Miller et al. 2010). The disease is responsible for high morbidity and mortality including enhanced stress and decreased egg production and hatchability in chicken (DoAH 2016b; Alexander 2000a). It has been reported that about 600 outbreaks of endemic NCD killed more than 20,000 chickens in from 2002 to 2006 although vaccination prevented more than one million birds (Sharma 2010). Although NCD can infect its natural hosts comprising more than 236 species of birds such as chickens, pigeons, turkeys, guinea fowl, Japanese quail and many wild birds of all ages (Alexander 2000a; Kaleta and Baldauf 1988), the data show that it gives about $9.5 \%$ CFR in domestic chicken and its effects in Nepalese wild birds are lacking.

\subsubsection{Peste des Petits Ruminants (PPR)}

Peste des petits ruminants (PPR), 'goat plague', or 'Kata', or 'Ovine rinderpest', or 'syndrome of stomatitis-pneumoenteritis' is caused by a PPR virus (PPRV) which is an enveloped negative-sense ssRNA virus belonging to the genus Morbillivirus of the family Paramyxoviridae (Gibbs et al. 1979; Dhar et al. 2002; Parida et al. 2015). The disease is highly contagious and acute in domestic and wild small ruminants, and is characterized by high fever, conjunctivitis, oculo-nasal discharges, necrotizing, erosive stomatitis, and diarrhea. In Nepal, PPR was first diagnosed in 1995 and has already been reported from Her 63 districts with its concentration in mid-hills and low land with a high morbidity ranging from 50-90\% and mortality ranging from 10-100\%, with $17.2 \%$ CFR although it has not been dealt with wild animals in the country (DoAH 2016a, b; Shrestha 2015).

\subsubsection{Rabies}

Rabies is an infectious disease caused by the rabies virus, a cylindrical neurotropic polystrain, negative-sense ssRNA virus of the genus Lyssavirus within the family Rhabdoviridae. The disease is epizootic in nature and its sylvatic or enzootic cycle is maintained by wild carnivores such as the members of the canids, mustelids, viverrids, procyonids, and chiropterans living in forest zones, national parks, or wildlife reserves although each strain is maintained in these particular hosts (CFSPH 2009b). Besides, its nature is zoonotic because it can principally be transmitted to humans and animals by the bite of an infected animal that contains virus in saliva. 
Several outbreaks of rabies have been reported in the canines and bovines in Nepal with its high morbidity and 100\% mortality of the livestock (DoAH 2016a, b). Data show that rabies kills about 100 livestock and 10-100 men per annum being the highest risk in the southern terai plain particularly due to agricultural lands, wildlife areas, and the open border with India (Devleesschauwer et al. 2016). Rabies is gaining significance in travel medicine particularly because there are many reports of bites and scratches into both tourists and foreign residents by rhesus monkeys (Macaca mulatta) that live anthropogenically near temples in many parts including the Kathmandu Valley, one of the oldest cities of the Himalayan countries (Devleesschauwer et al. 2016; Pandey et al. 2002). Although around 50,000 people seek post-exposure rabies prophylaxis (DoHS 2019b), there is no proof of rabies transmission following monkey attacks to the local and foreign travelers in Nepal (Shlim et al. 1991; Gongal 1998).

\subsubsection{Rinderpest Disease (Cattle Plague)}

Rinderpest disease, caused by a negative sense ssRNA virus called Morbillivirus genus of the Paramyxoviridae family affecting ungulates including wild and domestic animals, has been associated with the movement of warriors with the large cattle herds to carry foods and baggage (Roeder et al. 2013). Although the terai plain was 'home' of the disease, the exports of buffaloes and cattle from terai and Bhutan resulted in the common problem in the hills in 1866 (Spinage 2003). It caused several annual losses so that the GoN had to establish a Government Veterinary Service in 1939 (Spinage 2003). Nepal was declared as Rinderpest disease and infection free country in 2002, which demonstrates the strength of effective national epidemiological system in Nepal (DoAH 2016a, b). Mass vaccination to all bovids along the southern belt in the Indian border has been credited for the freedom from rinderpest within the country (Spinage 2003). It has been reported that the population of wild buffaloes in the Tsavo National Parks of Kenya declined by over $60 \%$ and the lesser kudus, the forest antelope by $90 \%$ in 1994-1995 following rinderpest infection indicating a huge economic loss in the wildlife (Rossiter 1996).

\subsubsection{Sheep Pox and Goat Pox}

Sheep pox and goat pox are caused by the antigenetically and physiochemically related the respective Sheeppox virus (SPPV) and goat pox virus (GTPV), the dsDNA virus, that belongs to the genus Capripoxvirus in Poxviridae family (Tulman et al. 2002). Both are transmitted by the contact to aerosols, respiratory droplets or contact with oronasal secretions of infected animals and by the mechanical methods, for example, the arthropod vectors like Stomoxys calcitrans and tsetse flies suggesting a critical role of climates in the transmission of the diseases (Kitching 
and Taylor 1985). Both diseases are underlying causes of a high morbidity but with only $1.6 \%$ CFR in sheep and goats in Nepal.

\subsection{Bacterial Species Leading MS Decline}

The presence of several bacterial species have been detected in environmental, clinical and veterinary samples like water, meat (buff, chicken, fish, mutton), feces, milk, urine, tissues, water, nasal swabs, ear swabs, and skin scrapings provided by farmers, researchers, and medical, and veterinary professionals. These species include Bacillus, Enterobacter, Escherichia, Haemophilus, Klebsiella, Micrococcus, Pasteurella multocida, Proteus, Salmonella of subgenus I or II group including S. agona, S. choleraesuis, S. enterica, S. enteritidis, S. gallinarum, S. pullorum, S. virchow, Shigella, and Staphylococcus (Chhetri et al. 2008; Maharjan et al. 2006; DoAH 2015, 2016a). These bacteria may solitarily or collectively induce the initiation of the diseases which are discussed in the next section (Photos 40.1).

\subsubsection{Actinomycosis}

Actinomycosis, an infrequent invasive disease, is caused by a Gram-positive filamentous bacterium called Actinomyces (Wong et al. 2011). It is a minor problem by occurrence in the country because few outbreaks of actinomycosis with few morbid cases have been reported.

Photo 40.1 Staphylococcus aureus cultured on Mannitol Salt Agar (MSA) plate from the clinical samples. (Photo kindly provided by Sagar Aryal (PhD Scholar), Tribhuvan University, Nepal)

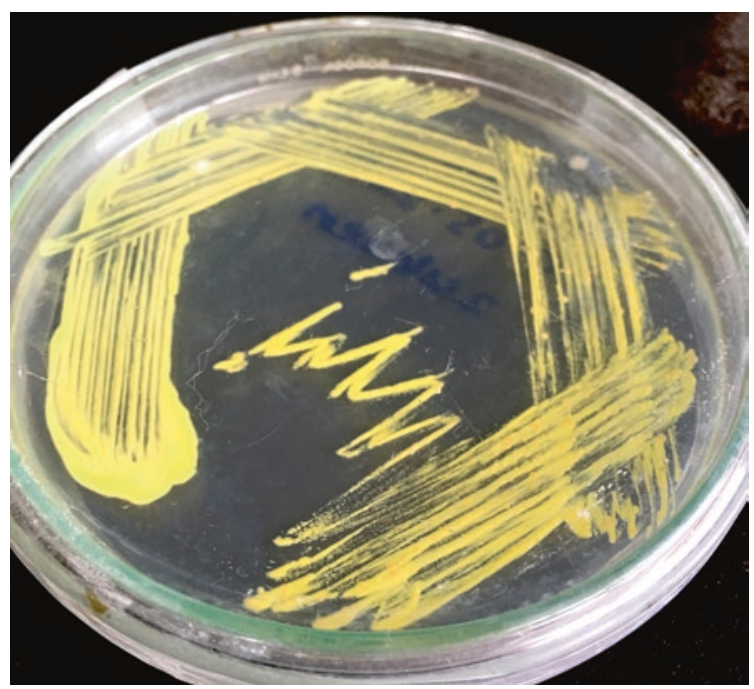




\subsubsection{Anthrax}

Anthrax is a zoonotic disease of humans and domestic and wild animals caused by Bacillus anthracis, a spore-bearing aerobic Gram-positive bacterium (Mwakapeje et al. 2018; Baillie and Read 2001). Based on the transmission routes and the clinical features, the disease has been classified into the cutaneous form, the gastrointestinal form, and the pulmonary form that may lead to immediate death (Mwakapeje et al. 2018). The disease has usually been sporadic and is responsible for several outbreaks in pigs, cattle, buffaloes, and horses with high morbidity leading up to 100\% CFR in Nepal (DoAH 2016a, b; Aryal 2016). Postmortem examination of a dead pregnant rhino revealed the presence of anthrax bacteria indicating the etiology of death of other several rhinos died in nature in the country (Anonymous 2017). In addition to overhunting, habitat degradation, exposure of rinderpest, and FMD, infection of anthrax has been attributed to the reduction of the population of Bos gaurus (Duckworth et al. 2016).

\subsubsection{Blackquarter}

Blackquarter or blackleg disease, a highly fatal disease in cattle, sheep, and goats, is caused by Clostridium chauvoei, an anaerobic spore-forming and toxin-producing motile Gram-positive highly pathogenic bacterium (Frey and Falquet 2015; Hatheway 1990). The disease occurs around water holes, well, in grazing areas, paddocks, and pens, and wells outbreaks may occur after flood and after excavation of soil because it may activate latent spores (Sultana et al. 2010; Hatheway 1990). The disease has a huge impact on the cattle herders because of the tremendous loss on the economy (Ayele et al. 2016; Hatheway 1990). It is an underlying cause of several outbreaks with high morbidity and about $1.7 \%$ CFR in the livestock in Nepal.

\subsubsection{Bovine Tuberculosis (BT)}

BT, an endemic zoonotic disease of the cattle and buffaloes, is caused by Mycobacterium bovis, a slow-growing, aerobic bacterium called a bovine tubercle bacillus. The bacterium is highly virulent and its several strains have been recovered after milk, feces, and intradermal test of most of the areas of the country indicating a critical role of this pathogen in public health (Jha et al. 2007; Silwal et al. 2011; Joshi 2003; Pun et al. 2004). TB in Nepal has been reported in the half of the Nepalese population among which 5000-7000 deaths and 44,000 new cases occurs per annum (NTP 2016). Data show that new and old cases of low altitude people are highly infected compared to those in the mountainous region, however, M. tuberculosis-borne human TB confirmation has been the highest in mountains 
compared with other landscapes (NTP 2016). This indicates that the possibility of bovine TB exists in the public health in the low altitude which may synchronize with respect to the numbers of cattle and buffalo population. Zoonotic characteristics of TB indicate that it is critical to farmers, raw milk consumers, cattle exporters and businessmen, and butchers.

\subsubsection{Brucellosis}

Brucellosis is a highly contagious zoonotic disease caused by a Gram-negative bacterium of the genus Brucella. B. melitensis principally infects the reproductive tract of sheep and goats and causes ovine and caprine brucellosis characterized by abortion, retained placenta, and impaired fertility. B. ovis causes ovine epididymitis. $B$. abortus infects cattle and buffaloes and causes bovine brucellosis. $B$. suis causes swine brucellosis (Smith and Shorman 2019). All of these brucellosis are recorded in Nepal (Knox et al. 2000). The disease is transmitted vertically into the new babies via milk and reproductive tract discharges and blood transfusion and homo-and hetero-sexual activities (Burgess 1982). Interestingly, few cultural practices involving the handling of dung in the agricultural land and biogas plant, drinking of raw goat blood by the pregnant women, consumption of raw milk, liver, kidney, testis, and brain, and practicing of shepherding and animal husbandry in the closet space with high stock density and high stocking rate might be the underlying risk factors of endemicity of the brucellosis. Principally, the evidences of high prevalence rate (up to 32\%) and morbidity in the livestock of Nepal comes from the seroprevalence study of the disease of several outbreaks in the Bos grunniens, and its breeds with local hill cattle (Bos indicus), cattle, pigs, goats, dogs, sheep, and domestic and wild buffaloes (Smith and Shorman 2019; DoAH 2016a; Shrestha 2008a). The low mortality might be associated with different factors like pathogenicity of the bacterium that depends on the species, size of inoculum, portal of entry, mode of transmission, and immune status of the MS. Brucellosis has been a massive global economic issue because of the loss of income due to abortion, milk and meat production, low fertility of the animal hosts, and huge cost on control and prevention programs including drug therapy and mass vaccination.

\subsubsection{Chronic Respiratory Disease (CRD)}

Chronic respiratory disease (CRD) in chicken, turkeys, game birds, pigeons, and wild birds is caused by Mycoplasma gallisepticum that is evolutionarily related to the low \% Guanine and Cytosine Gram-positive Clostridiales (Weisburg et al. 1989; Ricketts et al. 2017). Serology examination shows about $9.5 \%$ prevalence in the chicken in the Nepal (DoAH 2015). 


\subsubsection{Colibacillosis $(\mathrm{COB})$}

Colibacillosis (COB) is a disease caused by a Gram-negative, non-acid-fast, nonspore-forming bacterium called Escherichia coli with mainly serogroups O78, O1, O2, O15, O55 in animals including chicken (Chart et al. 2000; Dho-Moulin and Fairbrother 1999). COB causes pericarditis, airsacculitis, and perihepatitis in chronic form and may cause death following septicemia (Dho-Moulin and Fairbrother 1999). Several COB outbreaks have caused a high morbidity leading about $4.1 \%$ of CFR of the Nepalese livestock indicating a massive impact on the economy of the country.

\subsubsection{Contagious Agalactia}

Contagious agalactia principally infects sheep and goats in which the disease is caused by a bacterium called Mycoplasma agalactiae (Kumar et al. 2014). However, principally, other species like $M$. capricolum, M. putrefaciens, M. mycoides capri, and $M$. mycoides (large colony forms) can cause this infection in goats (CFSPH 2009a; Lambert 1987) and various signs of mastitis, arthritis, and keratitis have been reported in few morbid cases in Nepal.

\subsubsection{Enterotoxemia or Pulpy Kidney}

Enterotoxemia is a disease primary of sheep and goats caused by the toxin of Clostridium perfringes type $\mathrm{C}$ and $\mathrm{D}$ that are normally found in small numbers in healthy animals (McDonel 1980). The disease develops when the numbers of bacteria are increased and the microenvironments of the gut become favorable to toxin production (Nagahama et al. 2015; Uzal et al. 2010). Its outbreak is presumably associated with the lack of immunity, the heavy GI infestation, the periods of greatest pasture growth (Leite-Browning 2007). This is possible during summer months when mass grazing practice is culturally conducted during the availability of the new, better, and grainy diet. Although its outbreaks, susceptibility, and morbidity are very high, its CFR is only about $2.4 \%$ in Nepal.

\subsubsection{Fowl Typhoid (FT)}

FT is an acute or chronic septicemic disease that is caused by $S$. pullorum-related bacterium called $S$. gallilnarum (Shivaprasad 2000). It primarily affects adult birds, but, grouse, guinea fowl, ostriches, parrots, peafowl, pheasants, quail, ring-necked 
doves, sparrows, and turkeys of all ages are susceptible. FT has contributed several outbreaks resulting in a high morbidity and about $7.6 \%$ of CFR in chicken indicating a huge massive impact on the Nepalese economy.

\subsubsection{Hemorrhagic Septicemia}

Hemorrhagic septicemia, occurring primarily in cattle and buffaloes and secondarily in wild elephants, is caused by a Gram-negative nonmotile coccobacillus bacterium called Pasteurella multocida (Tankaew et al. 2017; Narasimham 1946). The disease manifests fever, depression, salivation, and submandibular edema, acute respiratory distress, and septicemia (de Alwis 1984). The GoN has indicated its several outbreaks leading a high morbidity and about $5.9 \%$ of CFR in livestock that suggested a national concern in the economy and veterinary health.

\subsubsection{Infectious Coryza}

Infectious coryza (ICR) is an acute respiratory disease of chicken caused by Haemophilus paragallinarum, a Gram-negative bacterium (Blackall et al. 2005; Blackall 1999). ICR induces nasal and lacrimal discharges, facial swelling, and diarrhea reducing the growth and egg production in chicken (Han et al. 2016; Soriano et al. 2004). Although ICR induces very high morbidity, it has about $1.6 \%$ CFR in chicken in Nepal.

\subsubsection{Mastitis}

Mastitis is a common persistent inflammatory disease of livestock, principally the cattle, that is caused by mechanical, thermal and chemical injury and most importantly, the toxins released by various coliform bacteria, Staphylococcus albus, and S. epidermidis (Subedi and Dhakal 2002; Dhakal et al. 2007). The occurrence of mastitis is related to rainy season when temperature and humidity is high, and during first calving, and first month of parturition (Dhakal et al. 2007). Since the replacement of local cows by many European breeds for increasing milk production, several thousands of mastitis cases with CFR less than $1 \%$ have been reported in the country (Knox et al. 2000; DoAH 2016b). 


\subsubsection{Pullorum}

Pullorum disease or bacillary white diarrhea is caused by a Gram negative bacterium, Salmonella pullorum (Shivaprasad 2000). This disease highly affects the young birds, however, it has been recovered from many adult species like chicken, turkeys, quail, guinea fowl, pheasants, ducks, pigeons, sparrows, canaries, bullfinches, parrots, pigs, cattle, cats, dogs, foxes, mink, rabbits, guinea pigs, laboratory and wild rats, and chinchillas (Barrow and Freitas Neto 2011). In addition to transmission via transovarian cycle and cannibalism of infected carcasses, the bacterium is transmitted by bird-to-bird contact, wound contamination, and fecal contamination of feed, water, and litter (Berchieri et al. 2001). In Nepal, pullorum results in the high morbidity and about $11.0 \%$ CFR after several outbreaks in chicken indicating a huge impact on veterinary health and the consequent loss in economy.

\subsection{Parasitic Species Leading to MS Decline}

\subsubsection{External Parasitosis and Warble Myiasis}

The infestation with external parasites is quite important in Nepal because of their effects in the high morbidity and mortality (DoAH 2016a). For example, several species of Amblyomma, Anomalohimalaya, Argas, Boophilus, Dermacentor, Haemaphysalis, Ixodes, Nosomma, and Rhipicephalus in humans and domestic and wild vertebrates have been well recorded (Estrada-Pena and Jongejan 1999; Clifford et al. 1971a, b; Hoogstraal 1971; Daniel 1979; Apanaskevich et al. 2014; Mitchell 1979; Bohara and Shrestha 2016; Fegan and Glennon 1996; Pun et al. 2018; Ghimire et al. 2018).

The country is also rich in several species of mite, lice, flea, and mosquito faunal diversity in various hosts (Mitchell 1979). Mites cause skin disease called mange or acariasis that has resulted into high morbidity and <1\% CFR (DoAH 2015, 2016b). Lice including Mallophaga (bird lice) and Anoplura like Pediculus human capitis, P. h. corporis, and Pthirus pubis are the predominant lice species (Mitchell 1979; Poudel and Barker 2004).

Importantly, a total of 44 species of Anopheles mosquitoes have been identified in the country, however, only seven of them (Anopheles minimus, Anopheles fluviatilis, Anopheles annularis, Anopheles maculatus, Anopheles dravidicus, Anopheles pseudowillmori, and Anopheles willmori) have been found to be malarial vectors (Ghimire 2016; Darsie and Pradhan 1990). In the same way, Aedes aegypti, A. albopictus, Culex quenquifasciatus, Culex tritaeniorhynchus, and several unidentified species have been recorded from low lands to upper lands of the country (Dhimal et al. 2014b). Other species at various landscapes are Aedomyia, Armigeres, Heizmannia, Mansonia, Malaya, Mimoyia, Tripteroides, and Uranotaenia are also reported (Dhimal et al. 2014b; Pradhan and Darsie 1989; Darsie et al. 1993) 
indicating the possibility of either existence or import of other several unreported vector-borne diseases in this country. Notably, the adults of the Anopheles, Culex, and Aedes mosquitoes were found in animal habitat, human habitat, mixed habitat, and natural outdoor habitat, where as their larval forms are predominant in stream, seepage, water tanks, discarded tire, paddy fields, tree holes, and plastic drums at different landscape within the country (Dhimal et al. 2014b).

Notably, warble infestation or myiasis has predominantly been reported to lead $<1 \%$ death of livestock in the country (DoAH 2016b). Warble myiasis is caused by the infestation of a warble fly called Hypoderma species on the body of horses, goats, sheep, and humans. When the fly lays eggs on the legs, the hatching larva invades the connective tissues and migrates almost all body parts and produces a swelling called 'warble'.

\subsubsection{Coccidiosis}

Coccidiosis is a disease caused by spore forming protozoa called coccidia of the Eimeria genus traditionally, however, broadly, this term can be used for the infections led by various genera like Isospora, Cyclospora, Cryptosporidium, Toxoplasma, Sarcocystis, and Microsporidia. Various species of Eimeria, for example, E. acervulina, E. maxima, E. necatrix, E. tenella and E. brunetti have been reported in chicken that might get coccidiosis (Adhikari et al. 2008; Jayswal et al. 2014). Several outbreaks of coccidiosis with high morbidity and about $4 \%$ CFR have been reported in chicken in Nepal (DoAH 2015, 2016a, b). Interestingly, the presence of one or more species of Eimeria, Isospora, Cyclospora, Cryptosporidium, Toxoplasma, and Sarcocystis have been predominantly reported in the wild hosts like red panda, rabbit, Hodgson's Giant Flying Squirrel (Petaurista magnificus), deer, yak, and in the humans (DoAH 2015, 2016a; Lama et al. 2015; Bista et al. 2017; Koirala et al. 2016; Achhami et al. 2016; Byanju et al. 2011; Ghimire et al. 2005, 2007, 2010; Ghimire 2010, 2018; Ghimire and Mishra 2005). Among these coccidia, toxoplasmosis has been predominantly reported in humans and domestic animals like sheep and goats showing the possibility of infection with meat-eating habits and cat-rearing situations in the country (Subedi et al. 2018; Rai et al. 1996, 1999; Sah et al. 2017). Even, it was reported to be lower in the sheep of high altitude with arid climate compared to those of lower altitude with hot and humid climate suggesting the climate-guided infection of T. gondii (Subedi et al. 2018).

\subsubsection{Helminthiasis}

Several experiments revealed that the stools of one or more of the hosts like bats, pigs, cattle, buffaloes, sheep, goats, dogs, poultry, red panda, deer, rhesus and assamese macaques, elephants, rhinoceros, Hodgson's Giant Flying Squirrel (Petaurista 


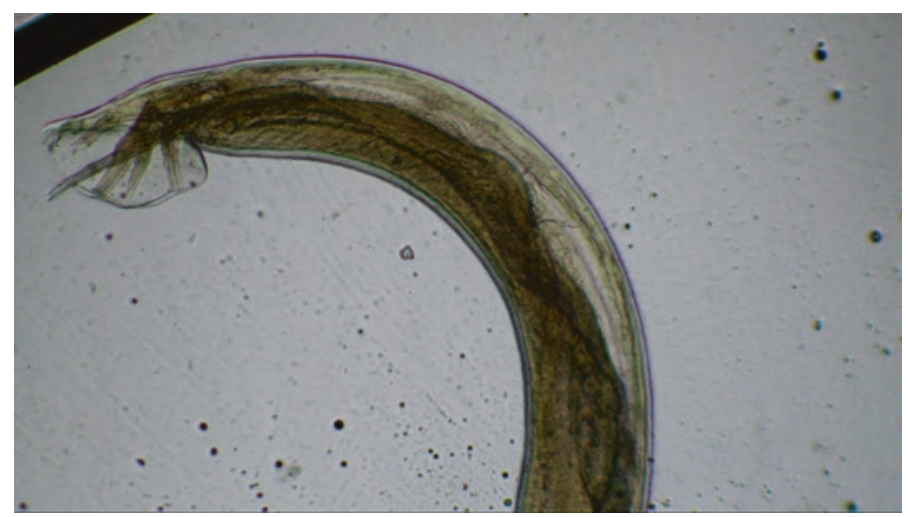

Photo 40.2 Microscopic image of Oesophagostomum species (X400 total magnification) extracted from the tissues of small intestine of goat and prepared from permanent slide. (Photo kindly provided by Anita Bhattarai, Department of Animal Breeding and Biotechnology, Agriculture and Forestry University, Rampur, Chitwan, Nepal)

magnificus), and yak contained Ancylostoma, Angiostrongylus, Anisakis, Ascaris, Baylisascaris, Capillaria, Chabertia, Dicrocoelium, Dictyocaulus, Diphyllobothrium, Dipyllidium, Dirofilaria, Fasciola hepatica, Fasciolopsis buski, Gnathostoma, Haemonchus, Moniezia, Nematodirus, Oesophagostomum, Ostertagia, Oxyuris, Paragonimus, Paramphistomum, Schistosoma, Spirometra, Strongyloides, Syphacia, Taenia, Toxocara, Trichinella, Trichostrongylus, and Trichuris (Devleesschauwer et al. 2014; DoAH 2015, 2016a, b; Achhami et al. 2016; Byanju et al. 2011; Ghimire 2010, 2018; Joshi et al. 1997; Ghimire 2018; Ghimire and Bhattarai 2019; Adhikari and Ghimire 2019; Ghimire and Adhikari 2019; Adhikari et al. 2018; Ghimire et al. 2019; Prajapati et al. 2018; Joship and Mahato 2013) (Photo 40.2). Several of these helminths cause echinococcosis or hydatidosis, cysticercosis, fasciolosis, schistosomiasis, trematodiasis, and soiltransmitted helminthiasis and all these induce about $1 \%$ CFR in Nepal. Among these infections, soil-transmitted helminths have been one of the major issues all over the country especially in the city areas particularly because of open defecation by domestic animals like dogs, cattle, and goats and seepage of sewage water in the soil.

\subsection{Fungal Species Leading to MS Decline}

\subsubsection{Mycotoxicosis}

Mycotoxicosis is the disease caused by the ingestion of cereal grains or foods containing toxic metabolites of certain fungi like Aspergillus flavus, Aspergillus parasiticus or Penicillium puberulum, Claviceps purpurea, Fusarium moniliforme, and 
Fusarium graminearum (Zain 2011). Several outbreaks of mycotoxicosis with various signs and pathologies leading high morbidity and about 4.0\% CFR have occurred in Nepal. Our primary observations indicated that mycotoxicosis is mainly associated with the use of hybrid seeds, lack of optimum post-harvesting duration, lack of proper storage, early harvesting, and carelessness in maintenance and management of environment during storage of grains, food, and animal fodders.

\subsubsection{Ringworm}

Ringworm or dermatophytosis characterized by red, itchy, scaly, and circular rash, and the loss of hair is caused by many fungi including Trichophyton, Microsporum, and Epidermophyton. The cases are very low, but critical in the veterinary health. In Nepalese people, ringworm has been critically experienced from many years in clinical settings (Paudel and Manandhar 2015; Reddy 2017; Mathur et al. 2012; Jha et al. 2019) resulting in the loss of economy, psychologic disorders, and high morbid cases especially in the immunocompromised, diabetic, and cancer patients.

\subsection{Vector-Borne Viral Diseases}

Nepalese veterinary and public health is highly affected by many vector-borne diseases that have massive impact on socio-economic status and socio-agricultural status. For example, bovine ephemeral fever (BEF) or Three Day Sickness is caused by bovine ephemeral fever virus (BEFV) that contains a negative ssRNA of the genus Ephemerovirus. As the virus has been isolated from various genera of Anophelines, Culicines, and Culicoides, they are implicated in the disease transmission (Walker 2020; Uren 1989). Disease is characterized by sudden onset of fever, stiffness, nasal and ocular discharges, depression, muscle tremors, and constipation (Wang et al. 2001; Burgess and Spradbrow 1977). The disease occurred with several outbreaks producing high morbidity and low mortality $(\mathrm{CFR}<1 \%)$ in livestock of Nepal (DoAH 2016b).

The public health is highly affected by the Chikungynya, Dengue, JE, and West Nile Fever in the country (Rutvisuttinunt et al. 2014). Chikungunya is caused by an icosahedral positive-sense ssRNA virus called Chikungunya virus (CHIKV) that falls in Alphavirus genus within Togaviridae family. CHIKV has 3 genotypes. After Chikungunya febrile cases were firstly reported in the patients from March to June 2013 (Pun et al. 2014), it has been dominantly reported in the terai regions of the country (Pandey et al. 2015, 2017).

Similar virus called Dengue virus (DV) causes Dengue that occurs in the form of Dengue fever (DF), Dengue hemorrhagic fever (DHF), and Dengue shock syndrome (DSS) is also dominant in the country. DV is an icosahedral positive-sense ssRNA virus that falls in genus Flavivirus within the family Flaviviridae. DV has 5 
serotypes and among them, only 4 serotypes (DEN-1, DEN-2, DEN-3 and DEN-4) have been reported in Nepal (Malla et al. 2008; DoHS 2017) indicating a serious threat to public health. Although the DV was firstly detected in a Japanese volunteer after his return to his country in 2004 (Takasaki et al. 2008), its sporadic cases and outbreaks were detected after 2006. The country had massive outbreaks in several districts in 2010 especially in Chitwan and Rupandehi districts. In a 4-year periods from 2006 to 2010, the DF cases increased from 5 districts to 24 districts indicating the rapid expansion of the disease in a wide geography of the country (Pun et al. 2014). Similar epidemics in 2013 and 2016 occurred infecting several people of middle hill districts suggesting the shifting of DV from subtropical areas to temperate zones (Gupta et al. 2018). More than 2000 DF cases as well as few deaths have been recently reported from 28 districts including Rupandehi, Jhapa, Mahottari, and Sarlahi at low altitude and Palpa, Arghakhachi, Rolpa, Pyuthan, and others at high altitude (DoHS 2019a). The shifting data are evidenced by the presence of CHIKV and DV vectors like Aedes aegypti and A. albopitus and the climatic variables like rainfall, temperature, and relative humidity are critical factors in the distribution of these vectors from the lowlands (80 masl) up to highlands such as Dhunche, Rasuwa districts (2100 masl) (Dhimal et al. 2015). The rapid expansion of the landscapes of these vectors and the associated viral diseases might be due to the increasing movement of viremic people, and means of transportation especially from the lowlands and endemic neighboring country like India, presence of vectors, and favorable environments via climate change (Narain 2008; Dhimal et al. 2014b). Thus, in addition to several socio-economic determinants like awareness, educational and social status, the role of climate change and the subsequent spread, acclimatization, establishment, and breeding of mosquitoes is critical to establish and transmit the diseases in a wide landscape. This principle also applies to the transmission of Zika virus ( $\mathrm{ZV})$ which is an enveloped and icosahedral positive-sense ssRNA virus belonging to the genus Flavivirus within Flaviviridae family. This is because since most cases of Zika virus are asymptomatic, it is not wrong to hypothesize the $\mathrm{ZV}$ existence in Nepal although a seroepidemiologic study could be used to prove this question (Wiwanitkit 2016). Nepal, as a member of HKH region, possesses few favorable environments of $\mathrm{ZV}$ transmission like shifting of Aedes vectors in highlands, public movement to the risk areas, lack of immunity in the people, climate change, and others (Dhimal et al. 2018).

Another vector-borne disease in Nepal is the West Nile Fever (WNF) caused by positive-sense ssRNA virus that belongs to the genus Flavivirus within the family Flaviviridae (Rutvisuttinunt et al. 2014). WNF possesses 8 different lineages with 2 main virulent lineages (Lineage 1 with clades $1 \mathrm{a}, 1 \mathrm{~b}$, and $1 \mathrm{c}$ and Lineage 2 ) responsible for outbreaks in humans, the clade $1 \mathrm{~b}$ containing Kunjin virus has already been reported to infect 3\% pigs in Nepal (Pant et al. 2006) suggesting existing risks of zoonosis in future. 


\subsection{Vector-Borne Bacterial Diseases}

Various emerging vector-borne diseases like rickettsioses and anaplasmosis have been reported in the Himalayan nations including Nepal. Rickettsioses caused by Rickettsia species are endemically found (Murphy et al. 2011; Murdoch et al. 2004). Anaplasmosis, transmitted by tick and characterized by severe anemia, increased heart rate, and hemoglobinuria, is caused by a Gram- negative rickettsial agent called Anaplasma. It has been detected in ticks as well as cattle, buffaloes, and dogs in Nepal suggesting one of the crucial vector-borne pathogens (Bohara and Shrestha 2016; DoAH 2016a; Adhikari et al. 1997). Scrub typhus is an emerging disease caused by a Gram-negative obligate intracellular ricketts called Orientia tsutsugamushi and transmitted by the blood sucking larva (chigger) of mite. The disease possesses a zoonotic tetrad with chiggers, rodents, scrub forest, and mites which helps maintain a sylvatic cycle among the chiggers and rodents (Nayak 2016). Thus, agricultural workers, travelers in endemic areas, people who are usual contact with mice and mites in houses or camping, and any form of temporary shelter are the high risk groups. Postearthquake consequences like human migration, overcrowding, and unsanitary conditions could increase the linkage among vector, rickets, and human which might represent truths of Earthquake Nepal-2015 (Nayak 2016; Upadhyaya et al. 2016; Blacksell et al. 2007; Sedhain and Bhattarai 2017). Although a neglected disease, it has high morbidity and mortality in the Nepalese population. Another typhus called murine typhus is caused by Rickettsia typhii that is transmitted by the bite of fleas (Xenopsylla cheopis) of rats. It is an endemic disease of Nepal where thousands of people get infected indicating a huge public health issues in the country (Zimmerman et al. 2008; Walter et al. 2012; Pradhan et al. 2012; Thompson et al. 2015).

\subsection{Vector-Borne Protozoan Diseases}

Several babesiosis outbreaks with low morbidity and low mortality have been reported (DoAH 2016b). Cattle, buffaloes, dogs, and horses have been found to be positive with Babesia infection (DoAH 2016a; Bohara and Shrestha 2016) and their death has been resulted following red urine (DoAH 2016b). The prevalence recorded is about $10 \%$ and the lowland landscape, the transboundary area near India, and the hilly regions of the country are endemic areas for babesiosis (Adhikari et al. 1997; Shrestha and Singh 1999; Dhakal et al. 1996; Thakuri et al. 1992).

There are many reports of theileriosis, caused by a protozoan species called Theileria parva, that outbreaks with high morbidity and low mortality (DoAH 2016b). Tsetse-borne trypanosomiasis caused high morbidity and very low mortality of livestock following many outbreaks (DoAH 2016b). The disease is predominant in the transboundary region of Nepal and India, especially the lowlands areas (Shrestha and Singh 1999). Importantly, dogs, buffaloes, and horses are found to be positive for Trypanosoma (DoAH 2016a; Adhikari et al. 1997). 
While vector-borne protozoa have low impact on health of livestock, their association to that of human is severe. For example, malaria, an endemic as well as imported disease primarily caused by Plasmodium vivax in general situation, $P$. falciparum in epidemic situation, and $P$. ovale in people with traveling history from Africa, has been recorded from many districts including mountainous areas (EDCD 2019). The trend of clinically suspected malaria case, slide positivity rate, and malaria caused by $P$. falciparum, $P$. vivax are decreasing year by year and is due to the increased health services and socio-economic status of the local people, and others (DoHS 2019a). The malariometric indicator analysis shows that although indigenous $P$. falciparum cases are rapidly decreasing, the indigenous $P$. vivax cases are slowly decreasing (Dhimal et al. 2014a). However, the trend of imported P. falciparum cases shows increasing (DoHS 2019a) indicating the critical role of human migration in the malaria transmission around the country.

It has also been suggested that the high risks and high risk zones of malaria includes foothills and river belts, forest fringe areas, forests of lowland area, inner valleys, and some terai districts (EDCD 2019; DoHS 2016, 2017). It is suggested that climate change and global warming have favored the breeding mechanisms of its vector, Anopheles spp., even in the high altitude leading to the probability of transmission of sporozoites. This has been evidenced by the fact that Anopheles fluviatilis was not detected above 1500 masl, has now been observed in Kashmir and Bhutan at heights of 2000 masl and more, indicating the role of climate change in vector spread in the Himalayas (Narain 2008).

In the same way, over the last decade, visceral leishmaniasis, caused by a protozoan hemoflagellate called Leishmania donovani and its vector sand fly, Phlebotomus argentipes, has spread towards the hill and mountain regions (Ostyn et al. 2015). Temperature, rainfall, and environment have been associated with the outbreaks. Notably, leishmaniasis has been reported from goats, buffaloes, and cattle indicating the possible role of domestic animals in the endemicity of the pathogen (Bhattarai et al. 2010; Khanal et al. 2010). The GoN has listed 18 districts as kalaazar endemic areas, however, new cases have been regularly reported in other districts (DoHS 2019a). Incidence of kala-azar (1 per 10,000 population) is at risk in the country leading to even more fatal in the presence of HIV/TB co-infection or in the lack of treatment on time (DoHS 2017).

\subsection{Vector-Borne Helminth Diseases}

Lymphatic filariasis (LF), caused by Wuchereria bancrofti and transmitted by Culex quinquefasciatus, is a neglected disease with $<1 \%$ to $39 \%$ prevalence rates in 61 endemic districts of Nepal with about 25 million populations at its risks (DoHS 2016, 2017). It showed various ranges of landscapes in distribution, for example, ranging from 92 masl to 1768 masl including the hill and mountain areas, especially the valleys and river basin areas of hilly districts with high disease burden suggesting the role of topographical landscapes in governing the establishment and distribution 
of the vectors (DoHS 2012, 2016, 2017). This presence data was satisfied by the observation of its main vector Culex quinquefasciatus that had been found up to 2100 masl indicating the shifting of diseases following climate change (Dhimal et al. 2014c). Since 2003, more than 100 million doses of drugs against LF have been administered to at-risk population and the transmission assessment survey in 25 districts in 2017 (DoHS 2019a) observed a significantly reduced prevalence of this disease suggesting government's successful achievement toward prevention of LF.

\subsection{Other Diseases Leading to MS Declines}

The public health is devastated by many food and water-borne diseases like bacterial diarrhea, hepatitis $\mathrm{A}$ and $\mathrm{E}$, and typhoid fever, sex-borne diseases like HIV/ AIDS and syphilis, airborne diseases like TB and acute respiratory illness, urineborne disease like leptospirosis, and vaccine-preventable diseases like diphtheria, influenza, measles, mumps, rubella, Haemophilus influenza type $b$ infections, hepatitis B, polio, tetanus, and typhoid that have a very high morbidity and mortality (DoHS 2017; Murdoch et al. 2004; Karkey et al. 2008; Woods et al. 2006; Maskey et al. 2006; Blacksell et al. 2007). Illness and or death of livestock following one or more of pneumonia (CFR $<1 \%$ ), poisoning (CFR 2\%), metritis (inflammation of the uterus), unclassified respiratory disease (CFR 3.7\%), respiratory sign diseases (CFR $2.1 \%$ ), milk fever $(\mathrm{CFR}<1 \%$ ), wound $(\mathrm{CFR}<1 \%)$, dystocia (CFR $<1 \%$ ), and skin lesions, seems to be critical in veterinary health. Besides, several outbreaks of Khari disease have been reported in the buffaloes in the Far-western regions. This has been probably associated with the higher indoor radiations, malnutrition, and parasitic infestation (Khanal et al. 2008, 2013).

Leptospirosis is an emerging disease of humans caused by Leptospira spp., a spirochete bacterium transmitted by food, water, soil contaminated by urine of infected hosts like domestic and wild vertebrates. The disease occurs during rainy season probably because of the high temperature, increased flood, and transmission of bacteria through open defection. It is usually underdiagnosed and underreported disease in Nepal where many cases are being reported due to the increased interests of scientists and veterinarians.

\subsection{Antibiotic Resistivity and Human and Wildlife Health}

Antibiotic resistance has been one of the biggest threats for environmental, public, and veterinary health resulting in the failure of treatment, cost of treatment, and the increase in morbidity and mortality of the MS in Nepal (Thapa et al. 2016; Baral et al. 2013; Belbase et al. 2017). This issue is evidenced by identification of the resistivity of one or more antibiotic/s to Acinetobacter, Citrobacter, Enterobacter, E. coli, Mycobacterium tuberculosis, Pseudomonas, Vibrio cholerae, Klebsiella 
pneumoniae, Proteus, Staphylococcus, Streptococcus pneumoniae, S. pyogenes, Shigella spp., S. typhi, S. paratyphi A, Salmonella species, Neisseria gonorrhoeae, in clinical, subclinical, veterinary, and environmental samples (Lamichhane et al. 2014; Chaudhary et al. 2017; Rijal et al. 2017; Bansal et al. 2015; Dhakal et al. 2007). Regarding antibiotic resistivity, the role of a fungus, Candida albicans is important (Photo 40.3). It is critical to note that Candida albicans and non-albicans groups are associated with the infections and are primarily present during immunosuppression. In this context, antibiotic resistivity might be dangerous because few antibiotics have been proved to be resisting by both albicans and non-albicans groups (Khadka et al. 2017) and patients can experience with fatal and chronic infections. The search of reliable antimicrobial surveillance data in animal health is particularly demanding, and prioritized because of the emergence of multi-drug resistance of mastitis, pyometra, colibacilosis, and tuberculosis. It has been shown that antibiotic resistivity is associated with the environmental density of the antibiotics spreading from focal points of drug distribution and the close community environment of antibiotic over- or mis-use (Walson et al. 2001). In a close community, sharing water sources for drinking, bathing, laundry, and crop irrigation is common, and the practice of open defecation not only enhances the frequency of antibiotic resistant genes, but also speeds up the presence of biocenose that comprises bacteria, parasites, viruses, fungi, and others in the aquaculture, raw fruits, and fresh vegetables, fish, meat, and other agricultural products (Walson et al. 2001; Rolain 2013). In addition, ethnically used common herbal medicines in the country act as antiseptic or disinfectant that may contribute to the selection and multiplication of drug-resistant bacteria (Shrestha and Dhillion 2003; Bhattarai 1997). In these contexts, several MS like arthropods, annelids, mollusks, and vertebrates including human and animals may act both as carriers and transmitters of antibiotic-resistant

\section{Photo 40.3 Candida} albicans cultured on Sabouraud Dextrose Agar (SDA) plate from the clinical samples. (Photo kindly provided by Sagar Aryal (PhD Scholar), Tribhuvan University, Nepal)

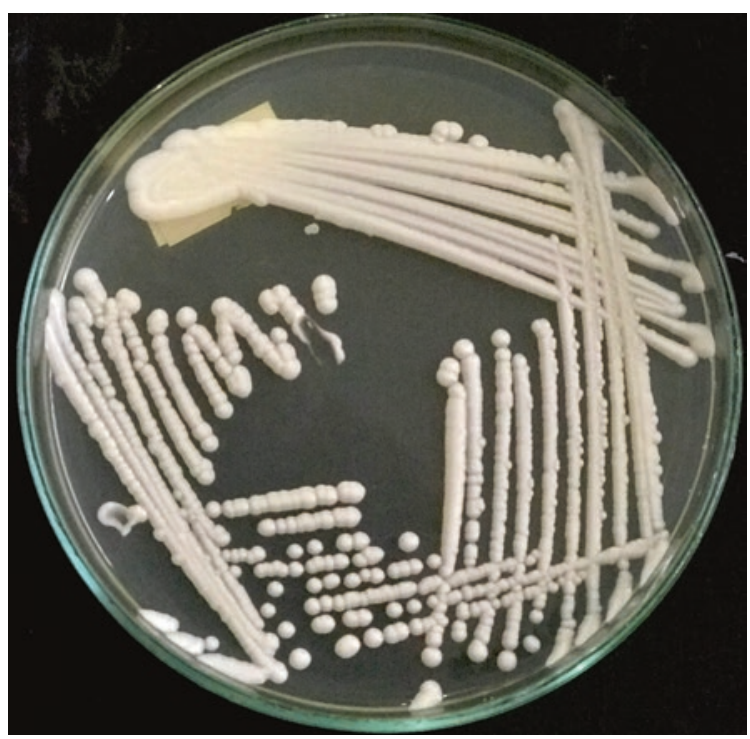


genes or biocenose all over the environment. This also suggests the possibility of the generation of drug-resistant genes in biocenose following the continuous feeding of several herbal plants by wild populations.

\subsection{The Generic Problem of Zoonoses}

As already discussed, ms has possibility to induce 60 zoonotic diseases including avian influenza, brucellosis, cysticercosis/taeniosis, hydatidosis, leptospirosis, neurocysticercosis, and toxoplasmosis that have played critical role in public health (DoHS 2017, 2019b). Deaths following snake bites and dog bites are also reported. In these cases, 32 deaths followed by the bite of more than 35,000 dogs and other animals and 20 deaths followed by more than 5600 snake bite cases have recently been reported throughout the country (DoHS 2019b). Critically, a total of 21 poisonous snakes include pit viper, krait, cobra, coral, and Russel's viper that are predominant in 26 low altitude districts and their bite cases generate 10\% mortality rates (DoHS 2019b). There are cases of cat and monkey bites although none of the deaths have been reported yet. Due to increase in people-wildlife conflicts, attacks by monkeys, jackals, bears, and other large mammals have been critical in the country and it is not included in this chapter here.

\subsection{Conclusions}

Since the beginning of agriculture civilization, the MS in Nepal has faced several ms infections leading their several morbidity and mortality. In addition, for several drivers of endangerment, the role of ms stands at the top. Although viral, bacterial, and parasitic diseases can lead to an endangerment process for a MS, the role of climate change and antibiotic resistivity and their consequences are critical. However, how these drivers play a role in the endangerment process have not been evaluated in situ. While lots of morbidity and mortality data are available for livestock, they are lacking in the context of wildlife. An integrated approach of research on human, wildlife, and livestock should be conducted so that we can collect many data related to the neglected diseases such as zoonotic diseases like brucellosis, reemerging diseases like many parasitic diseases, major killers like influenza, and vector-borne diseases like malaria, babesiasis, JE, and leishmaniasis. A coordinated control program including enhanced surveillance, isolation or rigorous precautions, early discharge, and alterations in antimicrobial usage can prevent the spread and emergence of drug resistance in the medical and veterinary offices (APUA 2008). In addition, search of effective, specific, and safe antigenic molecules to be used in vaccines and mass vaccination to prevent the future infections of ms into MS should be conducted. 


\section{References}

Abu Elzein EM, Housawi FM (1997) Severe long-lasting contagious ecthyma infection in a goat's kid. J Vet Med B 44(9):561-564

Achhami B, Sharma HP, Bam AB (2016) Gastro intestinal parasites of musk deer (Moschus chrysogaster Hodgson, 1839) in Langtang national park, Nepal. J Inst Sci Technol 21(1):71-75

Adams AJ, Pessier AP, Briggs CJ (2017) Rapid extirpation of a North American frog coincides with an increase in fungal pathogen prevalence: historical analysis and implications for reintroduction. Ecol Evol 7(23):10216-10232. https://doi.org/10.1002/ece3.3468

Adhikari RB, Ghimire TR (2019) Gastrointestinal Parasitism in Pigs of Shaktikhor Area in Central Southern Part of Nepal. International Youth Conference on Science, Technology and Innovation 2019, October 21-23, Kathmandu, Nepal, pp 930-934

Adhikari BN, Karki K, Gyanwali R (1997) Occurrence of blood parasites in Banke district: a clinical study. Bull Vet Sci Anim Hus Nepal 25:55-57

Adhikari A, Gupta R, Pant GR (2008) Prevalence and identification of coccidian parasite (Eimeria spp) in layer chicken of Ratnanagar municipality, Chitwan district, Nepal. J Nat Hist Mus 23:45-50

Adhikari BR, Shakya G, Upadhyay BP, KC KP, Shrestha SD, Dhungana GR (2011) Outbreak of pandemic influenza A/H1N1 2009 in Nepal. Virol J 8:133. https://doi. org/10.1186/1743-422X-8-133

Adhikari R, Maharjan M, Ghimire TR (2018) Presence of gastrointestinal parasites in the stool of bats in Shaktikhor area, Chitwan, Nepal. In: 23rd International Conference of International Academy of Physical Sciences (CONIAPS XXIII) on Advances in Physical Sciences to Achieve Sustainable Development Goals (November 16-18, 2018). Abstract: BIO-10. Published by Nepal Academy of Science and Technology, Khumaltar, Lalitpur, Nepal, pp 43

Adhikari RB, Maharjan M, Ghimire TR (2019) Assessment of gastrointestinal parasites in bat in Shaktikhor area, Central Southern Nepal. National Young Scientists Conference (NYSC)-2019 (April 23-24, 2019). Organized by Ministry of Industry, Tourism, Forests and Environment, State no. 3, Makwanpur, Nepal, p 120

Afonso CL, Tulman ER, Lu Z, Zsak L, Kutish GF, Rock DL (2000) The genome of fowlpox virus. J Virol 74(8):3815-3831. https://dx.doi.org/10.1128\%2Fjvi.74.8.3815-3831.2000

Alexander DJ (2000a) Newcastle disease and other avian paramyxoviruses. Rev Sci Tech Off Int Epiz 19(2):443-462

Alexander DJ (2000b) A review of avian influenza in different bird species. Vet Microbiol 74(1-2):3-13

Alexander DJ, Senne DA (2008) Chapter 3: Newcastle disease. In: Saif YM, Fadly AM, Glisson JR, LR McDougald, Nolan LK, Swayne DE (eds) Diseases of poultry, 12th edn. Blackwell Publishing Professional, Ames

Amatya SC (2016) Landslide disaster management in Nepal: a near-future perspective. NepalJapan Friendship Association of Water Induced Disaster (NFAD), Japan Department of Water Induced Disaster Management (DWIDM)

Anonymous (2009) Foot and mouth disease kills 5 blackbucks. My Republica, Nepal Republic Media Pvt. Ltd, Kathmandu

Anonymous (2017) Pregnant rhino died of 'anthrax' in CNP. The Kathmandu Post, Kantipur Publications Pvt. Ltd, Kathmandu, Nepal. Retrived: https://kathmandupost.com/ national/2017/08/01/pregnant-rhino-died-of-anthrax-in-cnp. Accessed 3 Feb 2020

Anonymous (2018) Flu claims life of 2-month-old; 10 dead in 2 weeks. The Kathmandu Post, Kantipur Publications Pvt. Ltd, Kathmandu, Nepal. Retrived: https://kathmandupost.com/ national/2018/01/10/flu-claims-life-of-2-month-old-10-dead-in-2-weeks. Accessed 3 Feb 2020

Apanaskevich DA, Duan W, Apanaskevich MA, Filippova NA, Chen J (2014) Redescription of Dermacentor everestianus Hirst (Acari: Ixodidae), a parasite of mammals in mountains of China and Nepal with synonymization of D. abaensis Teng and D. birulai Olenev. J Parasitol 100(3):268-278. https://doi.org/10.1645/13-369.1 
APUA (2008) Infection control: a potent antimicrobial resistance containment strategy. Alliance for the Prudent Use of Antibiotics (APUA) Volume 26, Issue 2-3. http://emerald.tufts.edu/ med/apua/news/vol26No2\&3.pdf. Accessed 18 Jan 2018

Aryal M (2016) Anthrax fear grips Palpa village. The Kathmandu Post, Kathmandu, Nepal. Retrived: https://kathmandupost.com/national/2016/01/19/anthrax-fear-grips-palpa-village. Accessed 3 Feb 2020

Ayele B, Tigre W, Deressa B (2016) Epidemiology and financial loss estimation of blackleg on smallholder cattle herders in Kembata Tambaro zone, Southern Ethiopia. Springerplus 5(1):1822. https://doi.org/10.1186/s40064-016-3541-2

Baillie L, Read TD (2001) Bacillus anthracis, a bug with attitude! Curr Opin Microbiol 4(1):78-81

Bansal BK, Gupta DK, Shafi TA, Sharma S (2015) Comparative antibiogram of coagulase-negative Staphylococci (CNS) associated with subclinical and clinical mastitis in dairy cows. Vet World 8(3):421-426. https://doi.org/10.14202/vetworld.2015.421-426

Baral R, Timilsina S, Jha P, Bhattarai N, Poudyal N, Gurung R, Khanal B, Bhattacharya S (2013) Study of antimicrobial susceptibility pattern of gram positive organisms causing UTI in a tertiary care hospital in eastern region of Nepal. Health Renaiss 11(2):119-124. https://doi. org/10.3126/hren.v11i2.8218

Barrow PA, Freitas Neto OC (2011) Pullorum disease and fowl typhoid-new thoughts on old diseases: a review. Avian Pathol 40(1):1-13. https://doi.org/10.1080/03079457.2010.542575

Belbase A, Pant ND, Nepal K, Neupane B, Baidhya R, Baidya R, Lekhak B (2017) Antibiotic resistance and biofilm production among the strains of Staphylococcus aureus isolated from pus/wound swab samples in a tertiary care hospital in Nepal. Ann Clin Microbiol Antimicrob 16:15. https://doi.org/10.1186/s12941-017-0194-0

Berchieri A Jr, Murphy CK, Marston K, Barrow PA (2001) Observations on the persistence and vertical transmission of Salmonella enterica serovars Pullorum and Gallinarum in chickens: effect of bacterial and host genetic background. Avian Pathol 30(3):221-231. https://doi. org/10.1080/03079450120054631

Berg TP (2000) Acute infectious bursal disease in poultry: a review. Avian Pathol 29(3):175-194. https://doi.org/10.1080/03079450050045431

Bhattarai NK (1997) Traditional herbal medicines used to treat wounds and injuries in Nepal. Trop Dr 27(Suppl 1):43-47. https://doi.org/10.1177/00494755970270s114

Bhattarai NR, Van der Auwera G, Rijal S, Picado A, Speybroeck N, Khanal B, De Doncker S, Das ML, Ostyn B, Davies C, Coosemans M, Berkvens D, Boelaert M, Dujardin JC (2010) Domestic animals and epidemiology of visceral leishmaniasis, Nepal. Emerg Infect Dis 16(2):231-237. https://doi.org/10.3201/eid1602.090623

Bista D, Shrestha S, Kunwar AJ, Acharya S, Jnawali SR, Acharya KP (2017) Status of gastrointestinal parasites in Red Panda of Nepal. PeerJ 5:e3767. https://doi.org/10.7717/peerj.3767

Blackall PJ (1999) Infectious coryza: overview of the disease and new diagnostic options. Clin Microbiol Rev 12(4):627-632

Blackall PJ, Christensen H, Beckenham T, Blackall LL, Bisgaard M (2005) Reclassification of Pasteurella gallinarum, [Haemophilus] paragallinarum, Pasteurella avium and Pasteurella volantium as Avibacterium gallinarum gen. nov., comb. nov., Avibacterium paragallinarum comb. nov., Avibacterium avium comb. nov. and Avibacterium volantium comb. nov. Int J Syst Evol Microbiol 55(Pt 1):353-362. https://doi.org/10.1099/ijs.0.63357-0

Blacksell SD, Sharma NP, Phumratanaprapin W, Jenjaroen K, Peacock SJ, White NJ, Pukrittayakamee S, Day NP (2007) Serological and blood culture investigations of Nepalese fever patients. Trans R Soc Trop Med Hyg 101(7):686-690. https://doi.org/10.1016/j. trstmh.2007.02.015

Blome S, Staubach C, Henke J, Carlson J, Beer M (2017) Classical swine fever-an updated review. Viruses 9(4):86. https://doi.org/10.3390/v9040086

Bohara T, Shrestha S (2016) A study on cattle tick and tick borne pathogens of midwestern Nepal. Nepal Vet J 33:23-27 
Boodhoo N, Gurung A, Sharif S, Behboudi S (2016) Marek's disease in chickens: a review with focus on immunology. Vet Res 47:119. https://doi.org/10.1186/s13567-016-0404-3

Boursnell MEG, Brown TDK, Foulds IJ, Green PF, Tomley FM, Binns MM (1987) Completion of the sequence of the genome of the coronavirus avian infectious bronchitis virus. J Gen Virol 68(Pt 1):57-77. https://doi.org/10.1099/0022-1317-68-1-57

Budha PB, Naggs F, Backeljau T (2015) Annotated checklist of the terrestrial gastropods of Nepal. ZooKeys 492:1-48. https://doi.org/10.3897/zookeys.492.9175

Burgess GW (1982) Ovine contagious epididymitis: a review. Vet Microbiol 7(6):551-575

Burgess GW, Spradbrow PB (1977) Studies on the pathogenesis of bovine ephemeral fever. Aust Vet J 53(8):363-368. https://doi.org/10.1111/j.1751-0813.1977.tb07952.x

Byanju R, Shrestha SP, Khanal DR (2011) Prevalence of gastrointestinal parasites in yaks of Lehe VDC, Manaslu conservation area. Nepal J Sci Technol 12:366-369. https://doi.org/10.3126/ njst.v12i0.6525

Cappelle J, Servan de Almeida R, Fofana B, Dakouo M, Balanca G, Gil P, Albina E, Gaidet N (2012) Circulation of avian influenza viruses in wild birds in inner Niger Delta, Mali. Influenza Other Respir Viruses 6(4):240-244. https://doi.org/10.1111/j.1750-2659.2011.00314.x

Cavanagh D (2007) Coronavirus avian infectious bronchitis virus. Vet Res 38(2):281-297. https:// doi.org/10.1051/vetres:2006055

CDC (2017) Avian influenza in birds. Retrived: https://www.cdc.gov/flu/avianflu/avian-in-birds. htm. Accessed 27 Mar 2018

CFSPH (2009a) Contagious agalactia. The Center for Food Security \& Public Health (CFSPH). Retrived: http://www.cfsph.iastate.edu/Factsheets/pdfs/contagious_agalactia.pdf

CFSPH (2009b) Rabies. The Center for Food Security \& Public Health (CFSPH). Retrived: http:// www.oie.int/fileadmin/Home/eng/Publications_\%26_Documentation/docs/pdf/rabies.pdf

Chart H, Smith HR, La Ragione RM, Woodward MJ (2000) An investigation into the pathogenic properties of Escherichia coli strains BLR, BL21, DH5alpha and EQ1. J Appl Microbiol 89(6):1048-1058. https://doi.org/10.1046/j.1365-2672.2000.01211.x

Chaudhary R, Thapa SK, Rana JC, Shah PK (2017) Surgical site infections and antimicrobial resistance pattern. J Nepal Health Res Counc 15(2):120-123. https://doi.org/10.3126/jnhrc. v15i2.18185

Chen H, Yuan H, Gao R, Zhang J, Wang D, Xiong Y, Fan G, Yang F, Li X, Zhou J, Zou S, Yang L, Chen T, Dong L, Bo H, Zhao X, Zhang Y, Lan Y, Bai T, Dong J, Li Q, Wang S, Zhang Y, Li H, Gong T, Shi Y, Ni X, Li J, Zhou J, Fan J, Wu J, Zhou X, Hu M, Wan J, Yang W, Li D, Wu G, Feng Z, Gao GF, Wang Y, Jin Q, Liu M, Shu Y (2014) Clinical and epidemiological characteristics of a fatal case of avian influenza A H10N8 virus infection: a descriptive study. Lancet 383(9918):714-721. https://doi.org/10.1016/s0140-6736(14)60111-2

Cheng TL, Rovito SM, Wake DB, Vredenburg VT (2011) Coincident mass extirpation of neotropical amphibians with the emergence of the infectious fungal pathogen Batrachochytrium dendrobatidis. Proc Natl Acad Sci U S A 108(23):9502-9507. https://doi.org/10.1073/ pnas. 1105538108

Chhetri VS, Pachhai IB, Poudel P, Bokkhim H, Dabadi YN (2008) Antibiotic resistant Escherichia coli in meat samples from Kathmandu valley. J Food Sci Technol Nepal 4:52-53

Chhetri BK, Perez AM, Thurmond MC (2010) Factors associated with spatial clustering of footand-mouth disease in Nepal. Trop Anim Health Prod 42(7):1441-1449. https://doi.org/10.1007/ s11250-010-9573-7

Chimeddorj B, Buuveibaatar B (2017) Situation analysis for the Mongolian saiga population, including the mass die-off due to an outbreak of goat plague. Retrived: http://www.saigaresourcecentre.com/background/news-archive/2017/2017/10/situation-analysis-for-the-mongolian-saiga-population,-including-the-mass-die-off-due-to-an-outbreak-of-goat-plague/. Accessed 15 Jan 2018

CIDRAP (2017) H5N8 strikes Nepal for first time; Vietnam reports H5N1, H5N6. Retrived: http://www.cidrap.umn.edu/news-perspective/2017/03/h5n8-strikes-nepal-first-time-vietnamreports-h5n1-h5n6. Accessed 28 Feb 2018 
Clifford CM, Hoogstraal H, Kohls GM (1971a) Ixodes hyatti, n. sp., and I. shahi, n. sp. (Acarina: Ixodidae), parasites of Pikas (Lagomorpha: Ochotonidae) in the Himalayas of Nepal and West Pakistan. J Med Entomol 8(4):430-438. https://doi.org/10.1093/jmedent/8.4.430

Clifford CM, Keirans JE, Hoogstraal H (1971b) Ixodes (Ixodes) nuttallianus Schulze: redescription of female, description of male, and hosts and ecology in Nepal (Acarina: Ixodidae). J Med Entomol 8(4):439-442. https://doi.org/10.1093/jmedent/8.4.439

Creevy KE (2018) Canine distemper overview. Retrived: http://www.merckvetmanual.com/generalized-conditions/canine-distemper/overview-of-canine-distemper. Accessed 15 Jan 2018

Daniel M (1979) Ixodid ticks of Barun Glacier region (the Nepal Himalaya). Folia Parasitologica (Praha) 26(4):337-341

Darsie RF Jr, Pradhan SP (1990) The mosquitoes of Nepal: their identification, distribution and biology. Mosq Syst 22(2):69-130

Darsie RF Jr, Courtney GW, Pradhan SP (1993) Notes on the mosquitoes of Nepal: III. Additional new records in 1992 (Diptera: Culicidae). Mosq Syst 25(3):186-191

de Alwis MCL (1984) Haemorrhagic septicaemia in cattle and buffaloes. Rev Sci Tech Off Int Epiz 3(4):707-730

Devleesschauwer B, Ale A, Torgerson P, Praet N, Maertens de Noordhout C, Pandey BD, Pun SB, Lake R, Vercruysse J, Joshi DD, Havelaar AH, Duchateau L, Dorny P, Speybroeck N (2014) The burden of parasitic zoonoses in Nepal: a systematic review. PLoS Negl Trop Dis 8(1):e2634. https://doi.org/10.1371/journal.pntd.0002634

Devleesschauwer B, Aryal A, Sharma BK, Ale A, Declercq A, Depraz S, Gaire TN, Gongal G, Karki S, Pandey BD, Pun SB, Duchateau L, Dorny P, Speybroeck N (2016) Epidemiology, impact and control of rabies in Nepal: a systematic review. PLoS Negl Trop Dis 10(2):e0004461. https://doi.org/10.1371/journal.pntd.0004461

Dhakal IP, Jha R, Basnet B (1996) Common diseases of livestock at Pathivara VDC of Sankhuwasava. In: The 5th National Veterinary Conference, Nepal, 1996, pp 95-99

Dhakal IP, Dhakal P, Koshihara T, Nagahata H (2007) Epidemiological and bacteriological survey of buffalo mastitis in Nepal. J Vet Med Sci 69(12):1241-1245. https://doi.org/10.1292/ jvms.69.1241

Dhar P, Sreenivasa BP, Barrett T, Corteyn M, Singh RP, Bandyopadhyay SK (2002) Recent epidemiology of peste des petits ruminants virus (PPRV). Vet Microbiol 88(2):153-159. https://doi. org/10.1016/S0378-1135(02)00102-5

Dhimal M, Ahrens B, Kuch U (2014a) Malaria control in Nepal 1963-2012: challenges on the path towards elimination. Malar J 13:241. https://doi.org/10.1186/1475-2875-13-241

Dhimal M, Ahrens B, Kuch U (2014b) Species composition, seasonal occurrence, habitat preference and altitudinal distribution of malaria and other disease vectors in eastern Nepal. Parasit Vectors 7:540. https://doi.org/10.1186/s13071-014-0540-4

Dhimal M, Gautam I, Kreß A, Müller R, Kuch U (2014c) Spatio-temporal distribution of dengue and lymphatic filariasis vectors along an altitudinal transect in Central Nepal. PLoS Negl Trop Dis 8(7):e3035. https://doi.org/10.1371/journal.pntd.0003035

Dhimal M, Gautam I, Joshi HD, O'Hara RB, Ahrens B, Kuch U (2015) Risk factors for the presence of chikungunya and dengue vectors (Aedes aegypti and Aedes albopictus), their altitudinal distribution and climatic determinants of their abundance in Central Nepal. PLoS Negl Trop Dis 9(3):e0003545. https://doi.org/10.1371/journal.pntd.0003545

Dhimal M, Dahal S, Dhimal ML, Mishra SR, Karki KB, Aryal KK, Haque U, Kabir MI, Guin P, Butt AM, Harapan H, Liu QY, Chu C, Montag D, Groneberg DA, Pandey BD, Kuch U, Muller R (2018) Threats of Zika virus transmission for Asia and its Hindu-Kush Himalayan region. Infect Dis Poverty 7(1):40. https://doi.org/10.1186/s40249-018-0426-3

Dho-Moulin M, Fairbrother JM (1999) Avian pathogenic Escherichia coli (APEC). Vet Res 30(2-3):299-316

DoAH (2015) Annual technical report, fiscal year 2071/072 (2014/015) Government of Nepal, Ministry of Livestock Development, Department of Livestock Services, Directorate of Animal Health, Central Veterinary Laboratory, Tripureshwor, Kathmandu, Nepal 
DoAH (2016a) Annual technical report, 2072/073. Government of Nepal, Ministry of Livestock Development, Department of Livestock Services, Directorate of Animal Health, Central Veterinary Laboratory, Tripureshwor, Kathmandu, Nepal

DoAH (2016b) Six-monthly epidemiological bulletin January-June 2016 vol 12. Government of Nepal, Ministry of Livestock Development, Department of Livestock Services, Directorate of Animal Health, Central Veterinary Laboratory, Tripureshwor, Kathmandu, Nepal

Dobos P, Hill BJ, Hallett R, Kells DT, Becht H, Teninges D (1979) Biophysical and biochemical characterization of five animal viruses with bisegmented double-stranded RNA genomes. J Virol 32(2):593-605

DoHS (2012) Annual report: Department of Health Services: 2067/68 (2010/2011). Government of Nepal, Ministry of Health, Department of Health Services (DoHS), Kathmandu

DoHS (2016) Annual report: Department of Health Services: 2071/72 (2014/2015). Government of Nepal, Ministry of Health, Department of Health Services (DoHS), Kathmandu

DoHS (2017) Annual report, Department of Health Services 2072/73 (2015/2016). Government of Nepal, Ministry of Health, Department of Health Services (DoHS), Kathmandu

DoHS (2019a) Annual report: Department of Health Services 2074/75 (2017/18). Government of Nepal, Ministry of Health and Population, Department of Health Services, Kathmandu

DoHS (2019b) National guideline for rabies prophylaxis in Nepal (2019). Department of Health Services, Epidemiology and Disease Control Division, Teku, Kathmandu

Dortmans JCFM, Koch G, Rottier PJM, Peeters BPH (2011) Virulence of Newcastle disease virus: what is known so far? Vet Res 42(1):122. https://doi.org/10.1186/1297-9716-42-122

Duckworth JW, Sankar K, Williams AC, Samba Kumar N, Timmins RJ (2016) Bos gaurus. The IUCN red list of threatened species, pp 1-29. https://dx.doi.org/10.2305/IUCN.UK.2016-2. RLTS.T2891A46363646.en

Dudley A (2017) As poaching practices shrink, Nepal's wildlife faces another challenge. Pacific Standard, The Social Justice Foundation, Santa Barbara

Duffus ALJ, Waltzek TB, Stöhr AC, Allender MC, Gotesman M, Whittington RJ, Hick P, Hines MK, Marschang RE (2015) Distribution and host range of ranaviruses. In: Gray MJ, Chinchar VG (eds) Ranaviruses: lethal pathogens of ectothermic vertebrates. Springer International Publishing AG, Cham, pp 9-57

EDCD (2019) National malaria treatment protocol. Epidemiology and Disease Control Division (EDCD), Department of Health Services, Kathmandu, Nepal. Retrived: http://www.edcd.gov. $\mathrm{np} /$ resources/download/national-malaria-treatment-protocol-2019. Accessed 4 Feb 2020

Estrada-Pena A, Jongejan F (1999) Ticks feeding on humans: a review of records on humanbiting Ixodoidea with special reference to pathogen transmission. Exp Appl Acarol 23(9):685-715. https://doi.org/10.1023/A:1006241108739

FAO/EuFMD (2020) Global Monthly Report. Foot-and-Mouth Disease Situation - November 2019. Rome, FAO. http://www.fao.org/3/ca6793en/ca6793en.pdf

Fegan D, Glennon J (1996) Intra-aural ticks in Nepal. Lancet 348(9037):1313. https://doi. org/10.1016/s0140-6736(05)65794-7

Ferris NP, Donaldson AI, Shrestha RM, Kitching RP (1992) A review of foot and mouth disease in Nepal. Rev Sci Tech 11(3):685-698. http://dx.doi.org/10.20506/rst.11.3.625

Fey SB, Siepielski AM, Nusslé S, Cervantes-Yoshida K, Hwan JL, Huber ER, Fey MJ, Catenazzi A, Carlson SM (2015) Recent shifts in the occurrence, cause, and magnitude of animal mass mortality events. Proc Natl Acad Sci 112(4):1083-1088. https://doi.org/10.1073/pnas.1414894112

Field IC, Meekan MG, Buckworth RC, Bradshaw CJ (2009) Chapter 4 susceptibility of sharks, rays and chimaeras to global extinction. Adv Mar Biol 56:275-363. https://doi.org/10.1016/ s0065-2881(09)56004-x

Frey J, Falquet L (2015) Patho-genetics of Clostridium chauvoei. Res Microbiol 166(4):384-392. https://doi.org/10.1016/j.resmic.2014.10.013

Fry EE, Lea SM, Jackson T, Newman JW, Ellard FM, Blakemore WE, Abu-Ghazaleh R, Samuel A, King AM, Stuart DI (1999) The structure and function of a foot-and-mouth disease 
virus-oligosaccharide receptor complex. EMBO J 18(3):543-554. https://doi.org/10.1093/ emboj/18.3.543

Gameel AA, Abu Elzein EME, Housawi FMT, Agib A, Ibrahim AO (1995) Clinico-pathological observations on naturally occurring contagious ecthyma in lambs in Saudi Arabia. Revue Elev Med Vet Pays Trop 48(3):233-235

Gates B (2014) The deadliest animal in the world. Mosquito Week. The Gates Notes LLC

Gautam M (2012) Bird flu infected chicken 'disappear'. The Kathmandu Post, Kathmandu

Geng Y, Wang KY, Zhou ZY, Li CW, Wang J, He M, Yin ZQ, Lai WM (2011) First report of a ranavirus associated with morbidity and mortality in farmed Chinese giant salamanders (Andrias davidianus). J Comp Pathol 145(1):95-102. https://doi.org/10.1016/j.jcpa.2010.11.012

Ghimire TR (2010) Pattern of intestinal parasites at open air defecation sites in Kathmandu Valley, Nepal. Trop J Health Sci 17(1):48-53. https://doi.org/10.4314/tjhc.v17i1.52808

Ghimire TR (2014) Parasites and parasitic diseases in Nepal. LAP LAMBERT Academic Publishing GmbH KG, Saarbrücken

Ghimire K (2016) Geographic distribution of malaria in Nepal. Kansas State University, Manhattan, Kansas, Department of Geography, College of Arts and Sciences

Ghimire T (2018) Investigating the contribution of parasites in the domestic animals researched at the Nepal Academy of Science and Technology (NAST). Int J Infect Dis 73:316. https://doi. org/10.1016/j.ijid.2018.04.4132

Ghimire TR, Adhikari RB (2019) Nematode parasites in the Gastrointestinal (GI) Tract of Goats in Ratnanagar,Chitwan, Nepal. International Youth Conference on Science, Technology and Innovation 2019, October 21-23, Kathmandu, Nepal, pp 921-924

Ghimire TR, Bhattarai N (2019) A survey of gastrointestinal parasites of goats in a goat market in Kathmandu, Nepal. J Parasit Dis 43(4):686-695. https://doi.org/10.1007/s12639-019-01148-w

Ghimire TR, Mishra PN (2005) Intestinal parasites and haemoglobin concentration in the people of two different areas of Nepal. J Nepal Health Res Counc 3(2):1-7. http://jnhrc.com.np/index. php/jnhrc/article/view/103/100

Ghimire TR, Mishra PN, Sherchand JB (2005) The seasonal outbreaks of Cyclospora and Cryptosporidium in Kathmandu, Nepal. J Nepal Health Res Counc 3(1):39-48

Ghimire TR, Mishra PN, Sherchand JB, Ghimire LV (2007) Bell's Palsy and cyclosporiasis: causal or coincidence? Nepal. J Neurosci 4(2):86-88

Ghimire TR, Ghimire LV, Shahu RK, Mishra PN (2010) Cryptosporidium and Cyclospora infection transmission by swimming. J Inst Med 32(1):43-45. https://doi.org/10.3126/jiom.v32i1.4003

Ghimire TR, Airee S, Bhattarai A (2018) Abundance, distribution, and effects of the ticks in the cattle of the Bhimdattanagar Municipality, Kanchanpur, Nepal Paper presented at the 23rd International Conference of International Academy of Physical Sciences (CONIAPS XXIII) on Advances in Physical Sciences to Achieve Sustainable Development Goals, Kathmandu, Nepal

Ghimire TR, Bhattarai A, Adhikari R (2019) Comparative survey of gastrointestinal adult helminthes in the sacrificed goats from Chitwan and Nawalpur in Nepal. In: Bhattarai N, Luitel H, Gautam G (eds) IGA Asian Regional Conference on Goats (ARCG 2019). 20-23 October, 2019. Faculty of Animal Science, Veterinary Science and Fisheries, Agriculture and Forestry University, Rampur, Chitwan, Nepal p 68

Gibbs EP, Taylor WP, Lawman MJ, Bryant J (1979) Classification of peste des petits ruminants virus as the fourth member of the genus Morbillivirus. Intervirology 11(5):268-274. https:// doi.org/10.1159/000149044

GoN/MoFSC (2014) Nepal national biodiversity strategy and action plan: 2014-2020. Government of Nepal, Ministry of Forests and Soil Conservation, Singha Durbar, Kathmandu

Gongal G (1998) Epidemiology of reported human rabies cases in Nepal, 1992-1996. J Inst Med 20(3\&4)

González-Suárez M, Revilla E (2014) Generalized drivers in the mammalian endangerment process. PLoS One 9(2):e90292. https://doi.org/10.1371/journal.pone.0090292 
Gupta BP, Tuladhar R, Kurmi R, Manandhar KD (2018) Dengue periodic outbreaks and epidemiological trends in Nepal. Ann Clin Microbiol Antimicrob 17:6. https://doi.org/10.1186/ s12941-018-0258-9

Han M-S, Kim J-N, Jeon E-O, Lee H-R, Koo B-S, Min K-C, Lee S-B, Bae Y-J, Mo J-S, Cho S-H, Jang H-S, Mo I-P (2016) The current epidemiological status of infectious coryza and efficacy of PoulShot Coryza in specific pathogen-free chickens. J Vet Sci 17(3):323-330. https://doi. org/10.4142/jvs.2016.17.3.323

Hatheway CL (1990) Toxigenic clostridia. Clin Microbiol Rev 3(1):66-98. https://dx.doi. org/10.1128\%2Fcmr.3.1.66

Hoogstraal H (1971) Haemaphysalis (Allophysalis) Warburtoni Nuttall: description of immature stages, adult structural variation, and hosts and ecology in Nepal, with a redefinition of the subgenus Allophysalis Hoogstraal (Ixodoidea: Ixodidae). J Parasitol 57(5):1083-1095

Isidoro-Ayza M, Lorch JM, Grear DA, Winzeler M, Calhoun DL, Barichivich WJ (2017) Pathogenic lineage of Perkinsea associated with mass mortality of frogs across the United States. Sci Rep 7(1):10288. https://doi.org/10.1038/s41598-017-10456-1

Jayswal RP, Gupta R, Shrestha SP (2014) Prevalence of Eimeria Schneider, 1875 in layer chicken of some poultry farms of Kathmandu and Lalitpur districts. J Nat Hist Mus 28:66-72. https:// doi.org/10.3126/jnhm.v28i0.14169

Jha VC, Morita Y, Dhakal M, Besnet B, Sato T, Nagai A, Kato M, Kozawa K, Yamamoto S, Kimura $\mathrm{H}$ (2007) Isolation of Mycobacterium spp. from milking buffaloes and cattle in Nepal. J Vet Med Sci 69(8):819-825. https://doi.org/10.1292/jvms.69.819

Jha B, Bhattarai S, Sapkota J, Sharma M, Bhatt CP (2019) Dermatophytes in skin, nail and hair among the patients attending out patient department. J Nepal Health Res Counc 16(41):434-437

Jnawali SR, Baral HS, Lee S, Acharya KP, Upadhyay GP, Pandey M, Shrestha R, Joshi D, Lamichhane BR, Griffiths J, Khatiwada AP, Subedi N, Amin R (compilers) (2011) The status of Nepal's mammals. The National Red List Series. Department of National Parks and Wildlife Conservation, Kathmandu, Nepal

Jones-Engel L, Engel GA, Heidrich J, Chalise M, Poudel N, Viscidi R, Barry PA, Allan JS, Grant R, Kyes R (2006) Temple monkeys and health implications of commensalism, Kathmandu, Nepal. Emerg Infect Dis 12(6):900-906. https://doi.org/10.3201/eid1206.060030

Joshi YP (2003) Prevalence of bovine tuberculosis among livestock and its relation with human tuberculosis in Kanchanpur district. Tribhuvan University, Kathmandu

Joship BR, Mahato SN (2013) Gastrointestinal parasitic diseases of buffaloes and implications of climate change for these diseases in Nepal. Buffalo Bull 32(2):1082-1087

Joshi BR, Gibbons LM, Jacobs DE (1997) Ostertagia nianqingtanggulaensis Kung \& Li, 1965 (Nematoda: Trichostrongyloidea) from sheep and goats at high altitudes in Nepal. J Helminthol 71(1):21-27

Kaleta EF, Baldauf C (1988) Newcastle disease in free-living and pet birds. In: Alexander DJ (ed) Newcastle disease, Developments in veterinary virology, vol 8. Springer, Boston, pp 197-246. https://doi.org/10.1007/978-1-4613-1759-3_12

Karkey A, Aryjal A, Basnyat B, Baker S (2008) Kathmandu, Nepal: still an enteric fever capital of the world. J Infect Dev Ctries 2(6):461-465. https://doi.org/10.3855/jidc.162

Karmacharya D, Manandhar S, Sharma A, Bhatta T, Adhikari P, Sherchan AM, Shrestha B, Bista M, Rajbhandari R, Oberoi M, Bisht K, Hero JM, Dissanayake R, Dhakal M, Hughes J, Debnath N (2015) Surveillance of Influenza A virus and its subtypes in migratory wild birds of Nepal. PLoS One 10(7):e0133035. https://doi.org/10.1371/journal.pone.0133035

Kato S, Fujisawa T, Enomoto N, Inui N, Nakamura Y, Suda T (2015) Severe respiratory failure associated with influenza B virus infection. Respirol Case Rep 3(2):61-63. https://doi. org/10.1002/rcr2.107

Keane PKA (1997) Factors affecting disease development. In: Brown JF, Ogle HJ (eds) Plant pathogens and plant diseases. Rockvale Publications, Armidale, pp 287-298

Khadka S, Sherchand JB, Pokhrel BM, Parajuli K, Mishra SK, Sharma S, Shah N, Kattel HP, Dhital S, Khatiwada S, Parajuli N, Pradhan M, Rijal BP (2017) Isolation, speciation and anti- 
fungal susceptibility testing of Candida isolates from various clinical specimens at a tertiary care hospital, Nepal. BMC Res Notes 10(1). https://doi.org/10.1186/s13104-017-2547-3

Khanal DR, Shah BR, Parajuli DB, Awasthi HR (2008) Assessment of possible involvement of ground radiation in the development of Khari disease in buffaloes of Darchula and Baitadi districts. Paper presented at the 5th National Conference on Science and Technology (NAST), Nepal Academy of Science and Technology (NAST), Khumaltar, Lalitpur, Nepal, 10-12 Nov, 2007

Khanal B, Picado A, Bhattarai NR, Van Der Auwera G, Das ML, Ostyn B, Davies CR, Boelaert M, Dujardin J-C, Rijal S (2010) Spatial analysis of Leishmania donovani exposure in humans and domestic animals in a recent kala azar focus in Nepal. Parasitology 137(11):1597-1603. https://doi.org/10.1017/s0031182010000521

Khanal DR, Knight AP, Joshi BR, Awasthi HR (2013) Management of Khari disease syndrome with pentasulfates supplementation in lactating buffaloes. Buffalo Bull 32(2):1051-1055

Khatri M, Sharma JM (2007) Modulation of macrophages by infectious bursal disease virus. Cytogenet Genome Res 117(1-4):388-393. https://doi.org/10.1159/000103202

Kitching RP, Taylor WP (1985) Transmission of capripoxvirus. Res Vet Sci 39(2):196-199

Kitching RP, Rendle R, Ferris NP (1988) Rapid correlation between field isolates and vaccine strains of foot-and-mouth disease virus. Vaccine 6(5):403-408. https://doi. org/10.1016/0264-410X(88)90139-9

Knox C, Gillies L, Joshi DD (2000) Veterinary public health in the Nepal Himalaya. Can Vet J 41(11):879-881

Koirala S, Katuwal HB, Achami B, Shah KB (2016) Parasites of Hodgson's giant flying squirrel (Petaurista magnificus). Int J Adv Res Biol Sci 3(7):8-13

Kumar A, Rahal A, Chakraborty S, Verma AK, Dhama K (2014) Mycoplasma agalactiae, an etiological agent of contagious agalactia in small ruminants: a review. Vet Med Int 2014:286752. https://doi.org/10.1155/2014/286752

Kwon S, Park J, Choi W-J, Koo K-S, Lee J-G, Park D (2017) First case of ranavirus-associated mass mortality in a natural population of the Huanren frog (Rana huanrenensis) tadpoles in South Korea. Anim Cells Syst 21(5):358-364. https://doi.org/10.1080/1976835 4.2017.1376706

Lama ST, Regmi GR, Lama R, Ghimire TR (2015) Prevalence of intestinal parasitic infections in free-ranging red panda Ailurus fulgens Cuvier, 1825 (Mammalia: Carnivora: Ailuridae) in Nepal. J Threat Taxa 7(8):7460-7464. https://doi.org/10.11609/jott.2113.7460-7464

Lamadrid A, Kelman I (2012) Climate change modeling for local adaptation in the Hindu Kush Himalayan region. Community, environment and disaster risk management, vol 11. Emerald Group Publishing Limited

Lambert M (1987) Contagious agalactia of sheep and goats. Rev Sci Tech Off Int Epiz 6(3):699-711

Lamichhane B, Thakur C, Jain SK (2014) Antibiotic resistance patterns of gram negative isolates in a tertiary care hospital of Nepal. Asian J Pharm Clin Res 7(3):30-33

Leite-Browning M (2007) Enterotoxemia (overeating disease) in sheep and goats. https://ssl.acesag.auburn.edu/pubs/docs/U/UNP-0089/UNP-0089-archive.pdf. Accessed 28 Mar 2018

Liu S, Chen J, Chen J, Kong X, Shao Y, Han Z, Feng L, Cai X, Gu S, Liu M (2005) Isolation of avian infectious bronchitis coronavirus from domestic peafowl (Pavo cristatus) and teal (Anas). J Gen Virol 86(Pt 3):719-725. https://doi.org/10.1099/vir.0.80546-0

Liu D, Shi W, Gao GF (2014) Poultry carrying H9N2 act as incubators for novel human avian influenza viruses. Lancet 383(9920):869. https://doi.org/10.1016/s0140-6736(14)60386-x

Maharjan M, Joshi V, Joshi DD, Manandhar P (2006) Prevalence of Salmonella species in various raw meat samples of a local market in Kathmandu. Ann N Y Acad Sci 1081:249-256. https:// doi.org/10.1196/annals.1373.031

Malla S, Thakur GD, Shrestha SK, Banjeree MK, Thapa LB, Gongal G, Ghimire P, Upadhyay BP, Gautam P, Khanal S, Nisaluk A, Jarman RG, Gibbons RV (2008) Identification of all dengue serotypes in Nepal. Emerg Infect Dis 14(10):1669-1670. https://doi.org/10.3201/ eid1410.080432 
Maskey AP, Day JN, Phung QT, Thwaites GE, Campbell JI, Zimmerman M, Farrar JJ, Basnyat B (2006) Salmonella enterica serovar Paratyphi A and S. enterica serovar Typhi cause indistinguishable clinical syndromes in Kathmandu, Nepal. Clin Infect Dis 42(9):1247-1253. https:// doi.org/10.1086/503033

Mathur M, Kedia SK, Ghimire RB (2012) "Epizoonosis of dermatophytosis": a clinico- mycological study of dermatophytic infections in central Nepal. Kathmandu Univ Med J (KUMJ) 10(37):30-33

Matsuzaki Y, Sugawara K, Mizuta K, Tsuchiya E, Muraki Y, Hongo S, Suzuki H, Nakamura K (2002) Antigenic and genetic characterization of influenza $C$ viruses which caused two outbreaks in Yamagata City, Japan, in 1996 and 1998. J Clin Microbiol 40(2):422-429

Matthews RE (1979) The classification and nomenclature of viruses. Summary of results of meetings of the International Committee on Taxonomy of Viruses in The Hague, September 1978. Intervirology 11(3):133-135

McDonel JL (1980) Clostridium perfringens toxins (type A, B, C, D, E). Pharmacol Ther 10(3):617-655. https://doi.org/10.1016/0163-7258(80)90031-5

Miller PJ, Decanini EL, Afonso CL (2010) Newcastle disease: evolution of genotypes and the related diagnostic challenges. Infect Genet Evol 10(1):26-35. https://doi.org/10.1016/j. meegid.2009.09.012

Mitchell RM (1979) A list of ectoparasites from Nepalese mammals, collected during the Nepal Ectoparasite program. J Med Entomol 16(3):227-233. https://doi.org/10.1093/ jmedent/16.3.227

Munster VJ, Baas C, Lexmond P, Waldenstrom J, Wallensten A, Fransson T, Rimmelzwaan GF, Beyer WE, Schutten M, Olsen B, Osterhaus AD, Fouchier RA (2007) Spatial, temporal, and species variation in prevalence of influenza A viruses in wild migratory birds. PLoS Pathog 3(5):e61. https://doi.org/10.1371/journal.ppat.0030061

Murdoch DR, Woods CW, Zimmerman MD, Dull PM, Belbase RH, Keenan AJ, Scott RM, Basnyat B, Archibald LK, Reller LB (2004) The etiology of febrile illness in adults presenting to Patan hospital in Kathmandu, Nepal. Am J Trop Med Hyg 70(6):670-675

Murphy H, Renvoisé A, Pandey P, Parola P, Raoult D (2011) Rickettsia honei infection in human, Nepal, 2009. Emerg Infect Dis 17(10):1865-1867. https://doi.org/10.3201/eid1710.101943

Mwakapeje ER, Høgset S, Fyumagwa R, Nonga HE, Mdegela RH, Skjerve E (2018) Anthrax outbreaks in the humans - livestock and wildlife interface areas of northern Tanzania: a retrospective record review 2006-2016. BMC Public Health 18(1):106. https://doi.org/10.1186/ s12889-017-5007-z

Nagahama M, Ochi S, Oda M, Miyamoto K, Takehara M, Kobayashi K (2015) Recent insights into Clostridium perfringens beta-toxin. Toxins 7(2):396-406. https://doi.org/10.3390/ toxins7020396

Nair V, Dunn JR (2018) Marek's disease. OIE terrestrial manual 2018. World Organisation for Animal Health (OIE), Paris. https://www.oie.int/fileadmin/Home/eng/Health_standards/ tahm/3.03.13_MAREK_DIS.pdf

Narain JP (2008) Climate change and its potential impact on vector-borne diseases. Health in South-East Asia, A SEARO Newsletter, pp 13-15

Narasimham CV (1946) A case of haemorrhagic septicaemia in an elephant. Indian Vet J 22:294

Nayak N (2016) Scrub typhus in Nepal. Nepal J Epidemiol 6(2):563-564. https://doi.org/10.3126/ nje.v6i2.15162

Ng ND, Carver S, Gotame M, Karmasharya D, Karmacharya D, Pradhan SM, Rana AN, Johnson CN, Lebarbenchon C (2019) Canine distemper in Nepal's Annapurna Conservation Area - Implications of dog husbandry and human behaviour for wildlife disease. PLoS ONE 14(12):e0220874. https://doi.org/10.1371/journal.pone.0220874

NRC (1993) The epidemiological transition: policy and planning implications for developing countries. In: Gribble JN, Preston SH (eds) Committee on population: Commission on Behavioral and Social Sciences and Education. National Research Council (NRC), The National Academies Press, Washington, DC, pp 1-288. https://doi.org/10.17226/2225 
NTP (2016) National tuberculosis program (NTP) Nepal: annual report 2072/73 (2016). Government of Nepal, Ministry of Health \& Population, Department of Health Services, National Tuberculosis Center, Thimi, Bhaktapur

OIE (2017a) Follow-up report no.1 (final report), report reference: reference OIE: 24028, report date: 11/06/2017, country: Nepal. World Organisation for Animal Health (OIE), Paris. https:// www.oie.int/wahis_2/temp/reports/en_fup_0000024028_20170614_180016.pdf

OIE (2017b) Follow-up report No.: 1, report reference: OIE Ref: 23112, Report Date: 05/03/2017, Country: Nepal. Immediate notifications and follow-up reports of highly pathogenic avian influenza (types H5 and H7). 12, rue de Prony 75017 Paris, France. https://www.oie.int/ wahis_2/temp/reports/en_fup_0000023112_20170306_150820.pdf

OIE (2017c) Global foot-and-mouth disease situation. OIE WAHID World Animal Health Information Database, FAO world reference laboratory for FMD (WRLFMD), FAO Global Animal Disease Information System (EMPRES-i). http://www.fao.org/fileadmin/user_upload/ eufmd/docs/FMD_monthly_reports/2017/January_2017_final.pdf

Osterhaus ADME, Rimmelzwaan GF, Martina BEE, Bestebroer TM, Fouchier RAM (2000) Influenza B virus in seals. Science 288(5468):1051-1053. https://doi.org/10.1126/ science.288.5468.1051

Ostyn B, Uranw S, Bhattarai NR, Das ML, Rai K, Tersago K, Pokhrel Y, Durnez L, Marasini B, Van der Auwera G, Dujardin J-C, Coosemans M, Argaw D, Boelaert M, Rijal S (2015) Transmission of Leishmania donovani in the hills of Eastern Nepal, an outbreak investigation in Okhaldhunga and Bhojpur districts. PLoS Negl Trop Dis 9(8):e0003966. https://doi. org/10.1371/journal.pntd.0003966

Pandey P, Shlim DR, Cave W, Springer MF (2002) Risk of possible exposure to rabies among tourists and foreign residents in Nepal. J Travel Med 9(3):127-131

Pandey BD, Neupane B, Pandey K, Tun MMN, Morita K (2015) Detection of Chikungunya virus in Nepal. Am J Trop Med Hyg 93(4):697-700. https://doi.org/10.4269/ajtmh.15-0092

Pandey K, Dev Pandey B, Rekha Chaurasiya R, Thakur M, Neupane B, Shah Y, Ngwetun M, Morita K (2017) Evidence of Chikungunya virus circulation in the Terai region of Nepal in 2014 and 2015. Trans R Soc Trop Med Hyg 111:294-299. https://doi.org/10.1093/trstmh/trx059

Pant GR, Lunt RA, Rootes CL, Daniels PW (2006) Serological evidence for Japanese encephalitis and West Nile viruses in domestic animals of Nepal. Comp Immunol Microbiol Infect Dis 29(2-3):166-175. https://doi.org/10.1016/j.cimid.2006.03.003

Parida S, Muniraju M, Mahapatra M, Muthuchelvan D, Buczkowski H, Banyard AC (2015) Peste des petits ruminants. Vet Microbiol 181(1):90-106. https://doi.org/10.1016/j.vetmic.2015.08.009

Paudel D, Manandhar S (2015) Dermatophytic Infections among the Patients Attending Di Skin Hospital and Research Center at Maharajgunj Kathmandu. J Nepal Health Res Counc 13(31):226-232

PEAN (2016) Analysis of pig and pork market system in Nepal (trans: Nepal PEA). CEAPRED/ SAMARTH - NMDP Pig Sector Project, Kathmandu, Nepal

Pedersen AB, Jones KE, Nunn CL, Altizer S (2007) Infectious diseases and extinction risk in wild mammals. Conserv Biol 21(5):1269-1279. https://doi.org/10.1111/j.1523-1739.2007.00776.x

Postel A, Jha VC, Schmeiser S, Becher P (2013) First molecular identification and characterization of classical swine fever virus isolates from Nepal. Arch Virol 158(1):207-210. https://doi. org/10.1007/s00705-012-1463-z

Poudel SK, Barker SC (2004) Infestation of people with lice in Kathmandu and Pokhara, Nepal. Med Vet Entomol 18(2):212-213. https://doi.org/10.1111/j.0269-283X.2004.00494.x

Pradhan SP, Darsie RF Jr (1989) New mosquito records for Nepal. J Am Mosq Control Assoc 5(1):21-24

Pradhan R, Shrestha U, Gautam SC, Thorson S, Shrestha K, Yadav BK, Kelly DF, Adhikari N, Pollard AJ, Murdoch DR (2012) Bloodstream infection among children presenting to a general hospital outpatient clinic in urban Nepal. PLoS One 7(10):e47531. https://doi.org/10.1371/ journal.pone.0047531 
Prajapati S, Karmacharya DK, Ghimire TR (2018) Why soil parasites in the habitat of the Chinese pangolin (Manis pentadactyla) matter?: A study in Taudolchaap Community Forest, Bhaktapur, Nepal. In: 23rd International Conference of International Academy of Physical Sciences (CONIAPS XXIII) on Advances in Physical Sciences to Achieve Sustainable Development Goals (November 16-18, 2018). Abstract: BIO-11. Published by Nepal Academy of Science and Technology, Khumaltar, Lalitpur, Nepal, pp 44

Pun MB, Prasai TP, Dhakal M, Jha VK, Shrestha KB, Jha VC, Sato T, Morita Y, Kozawa K, Kimura H (2004) Single intradermal tuberculin tests of milking buffaloes and cows in Nepal. Vet Rec 154(4): 124

Pun SB, Bastola A, Shah R (2014) First report of chikungunya virus infection in Nepal. J Infect Dev Ctries 8(6):790-792. https://doi.org/10.3855/jidc.3701

Pun SK, Guglielmone AA, Tarragona EL, Nava S, Maharjan M (2018) Ticks (Acari: Ixodidae) of Nepal: first record of Amblyomma varanense (Supino), with an update of species list. Ticks Tick-borne Dis 9(3):526-534. https://doi.org/10.1016/j.ttbdis.2018.01.010

Rai SK, Kubo T, Yano K, Shibata H, Sumi K, Matsuoka A, Uga S, Matsumura T, Hirai K, Upadhyay MP, Basnet SR, Shrestha HG, Mahajan RC (1996) Seroepidemiological study of Toxoplasma infection in central and western regions in Nepal. Southeast Asian J Trop Med Public Health 27(3):548-553

Rai SK, Matsumura T, Ono K, Abe A, Hirai K, Rai G, Sumi K, Kubota K, Uga S, Shrestha HG (1999) High Toxoplasma seroprevalence associated with meat eating habits of locals in Nepal. Asia Pac J Public Health 11(2):89-93. https://doi.org/10.1177/101053959901100207

Reddy KR (2017) Fungal infections (Mycoses): Dermatophytoses (Tinea, Ringworm). J Gandaki Med Coll-Nepal 10(1):1-13

Ricketts C, Pickler L, Maurer J, Ayyampalayam S, García M, Ferguson-Noel NM (2017) Identification of strain-specific sequences that distinguish a Mycoplasma gallisepticum vaccine strain from field isolates. J Clin Microbiol 55(1):244-252. https://doi.org/10.1128/ JCM.00833-16

Rijal BP, Satyal D, Parajuli NP (2017) High burden of antimicrobial resistance among bacteria causing pyogenic wound infections at a tertiary care hospital in Kathmandu, Nepal. J Pathogens 2017:7. https://doi.org/10.1155/2017/9458218

Roberts AJ, Wiedmann M (2003) Pathogen, host and environmental factors contributing to the pathogenesis of listeriosis. Cell Mol Life Sci 60(5):904-918. https://doi.org/10.1007/ s00018-003-2225-6

Roeder P, Mariner J, Kock R (2013) Rinderpest: the veterinary perspective on eradication. Philos Trans R Soc Lond B Biol Sci 368(1623):20120139. https://doi.org/10.1098/rstb.2012.0139

Rolain J-M (2013) Food and human gut as reservoirs of transferable antibiotic resistance encoding genes. Front Microbiol 4:173. https://doi.org/10.3389/fmicb.2013.00173

Rossiter P (1996) Epidemiological and clinical features of rinderpest in the 1990s. Annexe 4 Session 1: the distribution and nature of rinderpest. In: The world without rinderpest. Proceedings of the FAO Technical Consultation on the Global Rinderpest Eradication Programme Rome, Italy, 22-24 July 1996. Food and Agriculture Organization of the United Nations Rome, 1996. ISBN 92-5-103900-3. Retrived http://www.fao.org/3/w3246e/W3246E00.htm\#TOC

Rutvisuttinunt W, Chinnawirotpisan P, Klungthong C, Shrestha SK, Thapa AB, Pant A, Yingst SL, Yoon IK, Fernandez S, Pavlin JA (2014) Evidence of West Nile virus infection in Nepal. BioMed Cent Infect Dis 14:606. https://doi.org/10.1186/s12879-014-0606-0

Sah RP, Talukder MH, Alam MZ, Rahman AKMA, Singh UM (2017) Risk factors associated with Toxoplasma gondii seropositivity in randomly sampled goats of Sunsari district of Nepal. Nepal J Agric Sci 15:132-138

Sarkar S (2011) Climate change and disease risk in the Himalayas. Himal J Sci 6(8):7-8. https:// doi.org/10.3126/hjs.v6i8.4921

Scott P (2009) Contagious pustular dermatitis (Orf). National Animal Disease Information Service (NADIS) Ltd. http://www.nadis.org.uk/bulletins/contagious-pustular-dermatitis-(orf).aspx. Accessed 9 Apr 2018 
Sedhain A, Bhattarai GR (2017) Renal manifestation in scrub typhus during a major outbreak in Central Nepal. Indian J Nephrol 27(6):440-445. https://doi.org/10.4103/ijn.IJN_133_17

Sharma B (2010) Poultry production, management and bio-security measures. J Agric Environ 11:120-125. https://doi.org/10.3126/aej.v11i0.3659

Shivaprasad HL (2000) Fowl typhoid and pullorum disease. Rev Sci Tech 19(2):405-424

Shlim DR, Schwartz E, Houston R (1991) Rabies immunoprophylaxis strategy in travelers. J Wilderness Med 2(1):15-21. https://doi.org/10.1580/0953-9859-2.1.15

Shrestha TK (2000) Birds of Nepal field ecology, natural history and conservation (photographic field guide), vol 1. Mrs. Bimala Shrestha, Kathmandu

Shrestha TK (2001) Herpetology of Nepal: a field guide to amphibians and reptiles of TransHimalayan region of Asia. Mrs. Bimala Shrestha, Kathmandu

Shrestha B (2008a) Sero-prevalence of brucellosis in different species of meat animals of Nepal Bachelor of Veterinary Science (BVSc) \& Animal Husbandry (AH) internship report. Institute of Agriculture and Animal Science (IAAS), Tribhuvan University (TU), Kirtipur

Shrestha TK (2008b) Ichthyology of Nepal: a study of fishes of Himalayan waters. Himalayan Ecosphere

Shrestha DK (2015) PPR kills over 3000 sheep and goats in Jajarkot. Himalayan Times

Shrestha A (2019) First bird flu death reported in Nepal. The Himalayan TIMES, International Media Network Nepal (Pvt) Ltd, Kathmandu

Shrestha PM, Dhillion SS (2003) Medicinal plant diversity and use in the highlands of Dolakha district, Nepal. J Ethnopharmacol 86(1):81-96

Shrestha SP, Singh UM (1999) Study on blood protozoan disease in cattle of eastern Terai region. In: The 3rd National Workshop on Livestock and Fisheries Research in Nepal, Agricultural Research Station, Lumle, Kaski, Nepal, 26-28 June, 1999. National Animal Science Research Institute, Lalitpur, pp 123-125

Shrestha C, Upadhyaya M (2016) Situation analysis of foot and mouth disease (FMD) during 2001-2015 in Nepal. In: Six-monthly Epidemiological Bulletin-2016. Veterinary Epidemiology Center (VEC), Directorate of Animal Health (DoAH), Kathmandu, Nepal

Si Y, Wang T, Skidmore AK, De Boer WF, Li L, Prins HHT (2010) Environmental factors influencing the spread of the highly pathogenic avian influenza H5N1 virus in wild birds in Europe. Ecol Soc 15(3):26. https://doi.org/10.5751/ES-03622-150326

Silwal A, Joshi DD, Shrestha KB (2011) Study on prevalence of bovine tuberculosis in buffaloes and cattle of Dhading district Zoonoses and food hygiene news, vol 17. National Zoonoses and Food Hygiene Research Centre (NZFHRC), Kathmandu, Nepal, National Zoonoses and Food Hygiene Research Centre (NZFHRC), Kathmandu

Smith ME, Shorman M (2019) Brucellosis. https://www.ncbi.nlm.nih.gov/books/NBK441831/

Smith KF, Sax DF, Lafferty KD (2006) Evidence for the role of infectious disease in species extinction and endangerment. Conserv Biol 20(5):1349-1357. https://doi. org/10.1111/j.1523-1739.2006.00524.x

Snieszko SF (1974) The effects of environmental stress on outbreaks of infectious diseases of fishes. J Fish Biol 6(2):197-208. https://doi.org/10.1111/j.1095-8649.1974.tb04537.x

Soriano VE, Longinos GM, Fernandez RP, Velasquez QE, Ciprian CA, Salazar-Garcia F, Blackall PJ (2004) Virulence of the nine serovar reference strains of Haemophilus paragallinarum. Avian Dis 48(4):886-889. https://doi.org/10.1637/7188-033104r1

Spackman E, Stallknecht DE, Slemons RD, Winker K, Suarez DL, Scott M, Swayne DE (2005) Phylogenetic analyses of type A influenza genes in natural reservoir species in North America reveals genetic variation. Virus Res 114(1-2):89-100. https://doi.org/10.1016/j. virusres.2005.05.013

Spinage CA (2003) India and the east. In: Cattle plague: a history. Kluwer Academic/Plenum Publishers, Spring Street, New York, pp 467-496

Subedi K, Dhakal I (2002) Clinical mastitis in different breeds of cattle and buffaloes at Chitwan, Nepal. J Inst Agric Anim Sci 23:65-69 
Subedi S, Sharma B, Singh S, Bindari YR (2018) Sero-prevalence of Toxoplasma gondii in sheep in different geographical regions of Nepal. Vet Anim Sci 5:7-9. https://doi.org/10.1016/j. vas.2018.01.001

Sultana M, Ahad A, Biswas PK, Rahman MA, Barua H (2010) Black Quarter (BQ) disease in cattle and diagnosis of $\mathrm{BQ}$ septicaemia based on gross lesions and microscopic examination. Bangladesh J Microbiol 25(1):13-16. https://doi.org/10.3329/bjm.v25i1.4848

Sykes JE (2014) Canine Distemper virus infection. In: Canine and Feline infectious diseases. W.B. Saunders, Saint Louis, pp 152-165. https://doi.org/10.1016/B978-1-4377-0795-3.00015-6

Takasaki T, Kotaki A, Nishimura K, Sato Y, Tokuda A, Lim CK, Ito M, Tajima S, Nerome R, Kurane I (2008) Dengue virus type 2 isolated from an imported dengue patient in Japan: first isolation of dengue virus from Nepal. J Travel Med 15(1):46-49. https://doi. org/10.1111/j.1708-8305.2007.00165.x

Tankaew P, Singh-La T, Titaram C, Punyapornwittaya V, Vongchan P, Sawada T, Sthitmatee N (2017) Evaluation of an in-house indirect ELISA for detection of antibody against haemorrhagic septicemia in Asian elephants. J Microbiol Methods 134:30-34. https://doi.org/10.1016/j. mimet.2017.01.008

Thakuri KC (2012) Status of animal disease outbreak and identification of provisional disease free zone/ area, vol 2. Veterinary Epidemiology Centre, Kathmandu

Thakuri KC, Mahato SN, Thakur RP (1992) Diseases of cattle and buffaloes in the Koshi hills of Nepal: a retrospective study. Vet Rev (Kathmandu) 7(2):41-46

Thapa E, Thapa R, Singh A, Pokharel BM, Devkota U (2016) Antibiotic resistance pattern of bacterial isolates from post- tracheostomised patients attending tertiary care hospital in Nepal. J Inst Sci Technol 21(1):129-132. https://doi.org/10.3126/jist.v21i1.16064

Thompson CN, Blacksell SD, Paris DH, Arjyal A, Karkey A, Dongol S, Giri A, Dolecek C, Day N, Baker S, Thwaites G, Farrar J, Basnyat B (2015) Undifferentiated febrile illness in Kathmandu, Nepal. Am J Trop Med Hyg 92(4):875-878. https://doi.org/10.4269/ajtmh.14-0709

Tulman ER, Afonso CL, Lu Z, Zsak L, Sur J-H, Sandybaev NT, Kerembekova UZ, Zaitsev VL, Kutish GF, Rock DL (2002) The genomes of sheeppox and goatpox viruses. J Virol 76(12):6054-6061

Upadhyaya BP, Shakya G, Adhikari S, Rijal N, Acharya J, Maharjan L, Marasini BR (2016) Scrub Typhus: an emerging neglected tropical disease in Nepal. J Nepal Health Res Counc 14(33):122-127

Uren MF (1989) Bovine ephemeral fever. Aust Vet J 66(8):233-236

Uzal FA, Vidal JE, McClane BA, Gurjar AA (2010) Clostridium Perfringens toxins involved in mammalian veterinary diseases. Open Toxinol J 2:24-42

VEC (2016) FMD situation in Nepal. FMD Newsletter - Nepal 1(1):1-2

Walker PJ (2020) Overview of bovine ephemeral fever (Three-day sickness). MSD and the MSD Veterinary Manual. Merck Sharp \& Dohme Corp., a subsidiary of Merck \& Co., Inc., Kenilworth, NJ, USA. Retrived: https://www.msdvetmanual.com/generalized-conditions/ bovine-ephemeral-fever/overview-of-bovine-ephemeral-fever. Accessed 31 Jan 2020

Walson JL, Marshall B, Pokhrel BM, Kafle KK, Levy SB (2001) Carriage of antibiotic-resistant fecal bacteria in Nepal reflects proximity to Kathmandu. J Infect Dis 184(9):1163-1169. https://doi.org/10.1086/323647

Walter G, Botelho-Nevers E, Socolovschi C, Raoult D, Parola P (2012) Murine Typhus in returned travelers: a report of thirty-two cases. Am J Trop Med Hyg 86(6):1049-1053. https://doi. org/10.4269/ajtmh.2012.11-0794

Wang FI, Hsu AM, Huang KJ (2001) Bovine ephemeral fever in Taiwan. J Vet Diagn Invest 13(6):462-467. https://doi.org/10.1177/104063870101300602

Webster RG, Bean WJ, Gorman OT, Chambers TM, Kawaoka Y (1992) Evolution and ecology of influenza A viruses. Microbiol Rev 56(1):152-179

Weisburg WG, Tully JG, Rose DL, Petzel JP, Oyaizu H, Yang D, Mandelco L, Sechrest J, Lawrence TG, Van Etten J, Maniloff J, Woese CR (1989) A phylogenetic analysis of the myco- 
plasmas: basis for their classification. J Bacteriol 171(12):6455-6467. https://doi.org/10.1128/ jb.171.12.6455-6467.1989

WHO (2012) H5N1 avian influenza: timeline of major events. World Health Organization (WHO), Geneva. Retrived from: https://www.who.int/influenza/human_animal_interface/H5N1_ avian_influenza_update.pdf . Accessed 25 Jan 2020

Wilber MQ, Knapp RA, Toothman M, Briggs CJ (2017) Resistance, tolerance and environmental transmission dynamics determine host extinction risk in a load-dependent amphibian disease. Ecol Lett 20(9):1169-1181. https://doi.org/10.1111/ele.12814

Wilson RT (1997) Animal genetic resources and domestic animal diversity in Nepal. Biodivers Conserv 6(2):233-251. https://doi.org/10.1023/A:1018344103664

Wiwanitkit V (2016) Zika virus in Nepal. J Nepal Health Res Counc 14(32):71

Wong VK, Turmezei TD, Weston VC (2011) Actinomycosis. Br Med J (BMJ) 343:d6099. https:// doi.org/10.1136/bmj.d6099

Woods CW, Murdoch DR, Zimmerman MD, Glover WA, Basnyat B, Wolf L, Belbase RH, Reller LB (2006) Emergence of Salmonella enterica serotype Paratyphi A as a major cause of enteric fever in Kathmandu, Nepal. Trans R Soc Trop Med Hyg 100(11):1063-1067. https://doi. org/10.1016/j.trstmh.2005.12.011

Yan C, Liang L-J, Zheng K-Y, Zhu X-Q (2016) Impact of environmental factors on the emergence, transmission and distribution of Toxoplasma gondii. Parasit Vectors 9:137. https://doi. org/10.1186/s13071-016-1432-6

Youzbashi E, Marschall M, Chaloupka I, Meier-Ewert H (1996) Distribution of influenza C virus infection in dogs and pigs in Bavaria. Tierarztl Prax 24(4):337-342

Zachar T, Popowich S, Goodhope B, Knezacek T, Ojkic D, Willson P, Ahmed KA, Gomis S (2016) A 5-year study of the incidence and economic impact of variant infectious bursal disease viruses on broiler production in Saskatchewan, Canada. Can J Vet Res 80(4):255-261

Zain ME (2011) Impact of mycotoxins on humans and animals. J Saudi Chem Soc 15(2):129-144. https://doi.org/10.1016/j.jscs.2010.06.006

Zanaty A, Arafa A-S, Hagag N, El-Kady M (2016) Genotyping and pathotyping of diversified strains of infectious bronchitis viruses circulating in Egypt. World J Virol 5(3):125-134. https://doi.org/10.5501/wjv.v5.i3.125

Zimmerman MD, Murdoch DR, Rozmajzl PJ, Basnyat B, Woods CW, Richards AL, Belbase RH, Hammer DA, Anderson TP, Reller LB (2008) Murine typhus and febrile illness, Nepal. Emerg Infect Dis 14(10):1656-1659. https://doi.org/10.3201/eid1410.080236 